
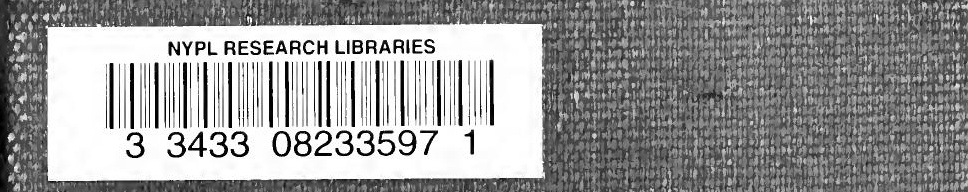
mo

is id

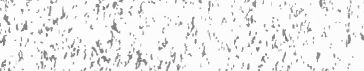

of

ations

as

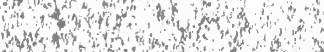

ow

mo

A

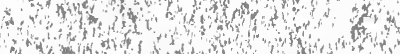

and

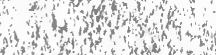

Sto.

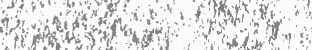

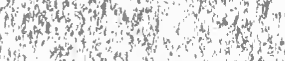

and

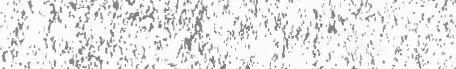

(1)

(x)

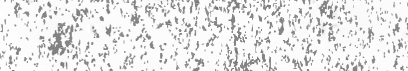

of

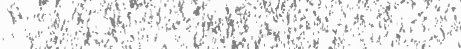

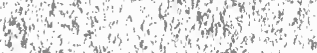

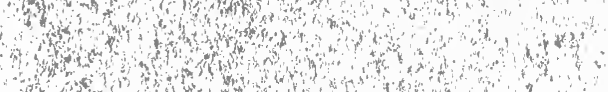

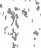

5

12 is

is

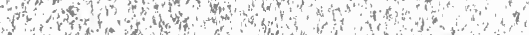

in

and

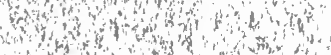

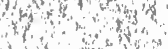

a

of

in

A

A

- $x^{2}$

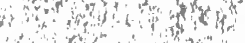

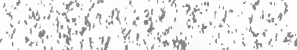

and

4

tit

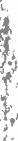

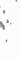



and

ty 7 .

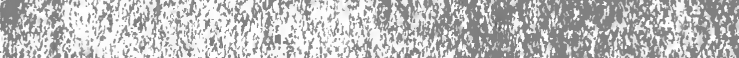

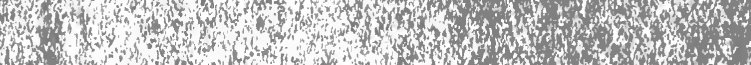
iting

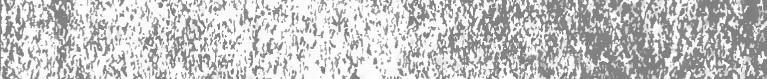

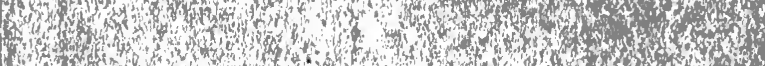

19.

1.7.

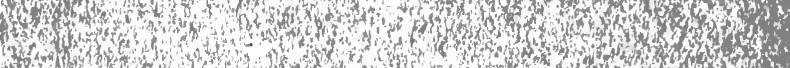

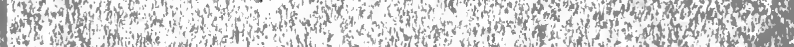

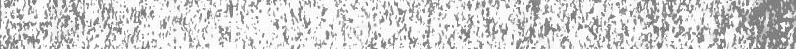

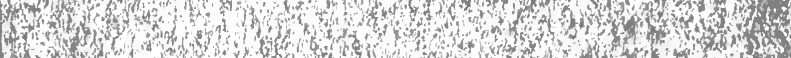

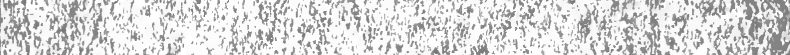
5.

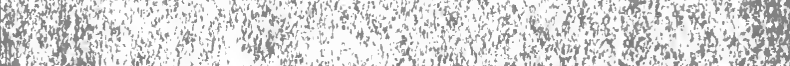

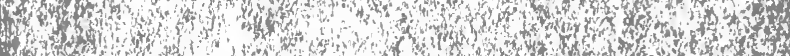

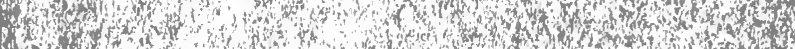

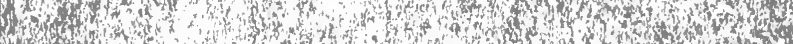

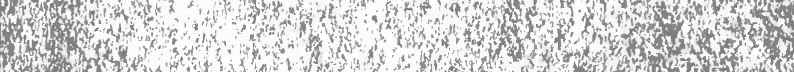

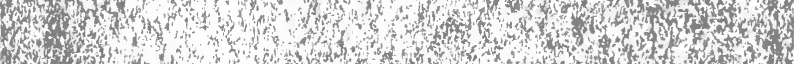

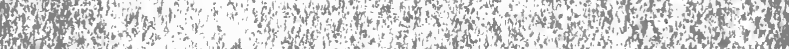

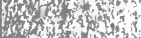

mintoris

wint

15y

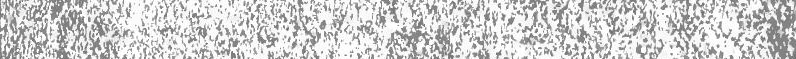
(4)

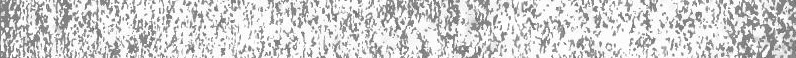

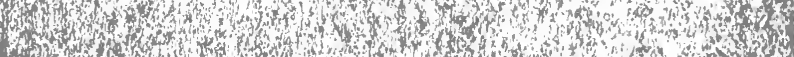
* 73 \%

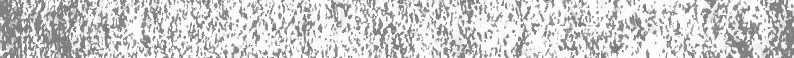

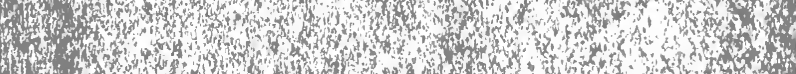

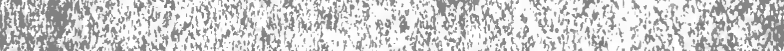

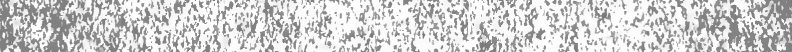

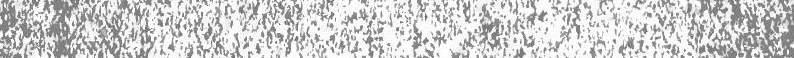

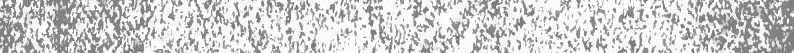

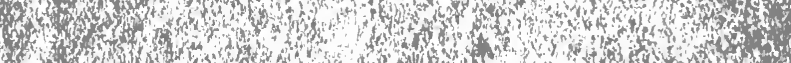

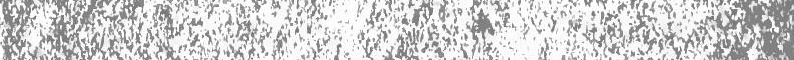

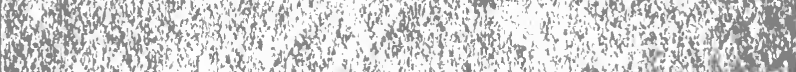
1536) ifond

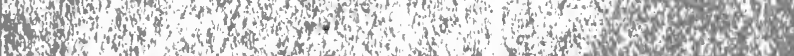

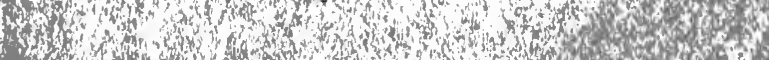

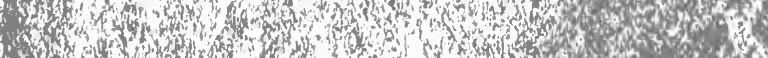

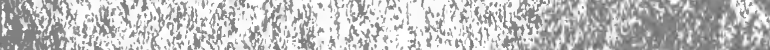
M

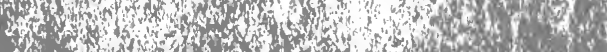



Digitized by the Internet Archive in 2007 with funding from Microsoft Corporation 


\section{Mark $\widetilde{C}$ waín}

\section{and the bappe Island}





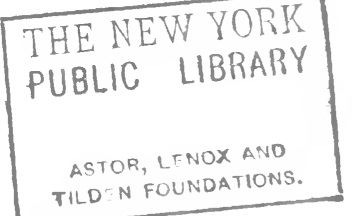




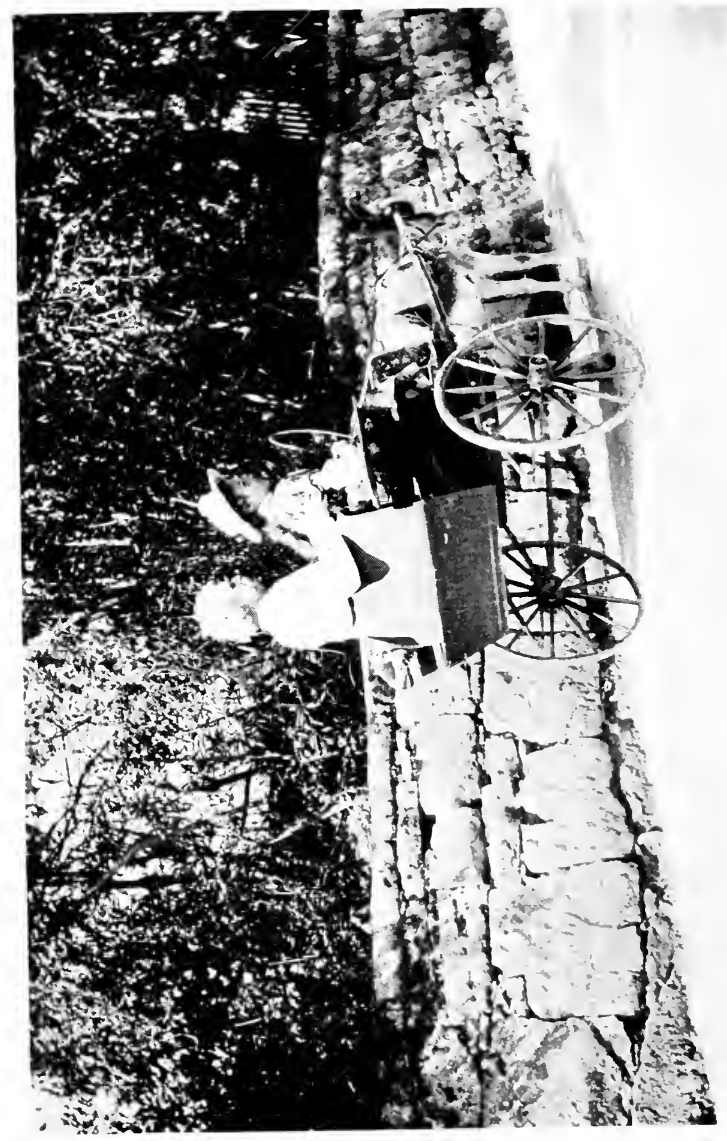

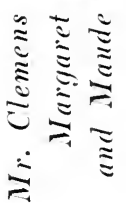




\title{
Mark Twain
}

and

\section{The Happy Island}

\author{
by \\ Elizabeth Wallace \\ Author of \\ A Garden of Paris
}

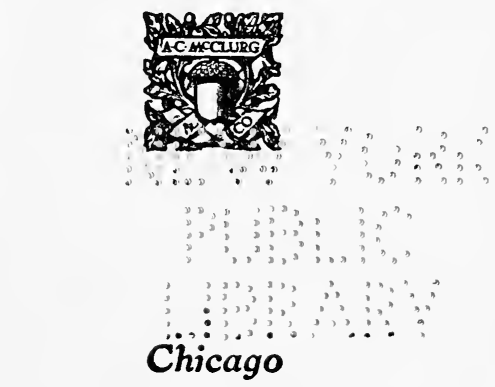

A. C. McClurg \& Co.

1913 


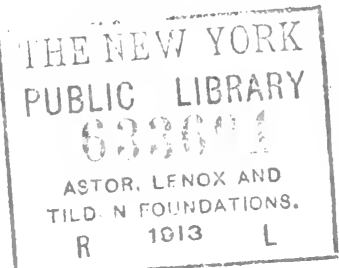

\section{Copyright}

A. C. McCLURG \& CO.

1913

Published April, 1913

Copyrighted in Great Britain

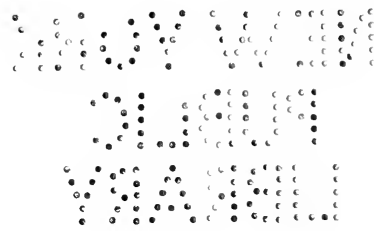

W. F. HALL PRINTING COMPANY, CHICAGO 


\section{To all those}

who knew and loved Mark Twain on the Happy Island, this little book is hopefully dedicated 



\section{A NOTE OF INTRODUCTION}

7 HIS little story of "The Happy Island" 1 has a place of its own in Mark Twain literature, in that it presents an idyllic picture. of our philosopher-humorist in the serener days of his later life-a picture of which the author herself was a part.

Mark Twain always loved Bermuda, from the first day of his first visit, to that last day of his final visit, when he sailed away, with the shadows already gathering just ahead. Miss Wallace's story is a tender one, showing him still full of life and health, and of that gracious sympathy with childhood which was always one of his chief characteristics and added comfort to his later years.

The world will be the better and Mark Train's memory the sweeter for these gentle chapters.

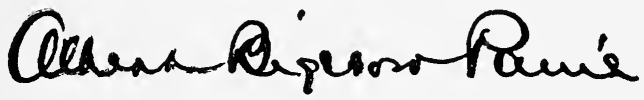





\section{CONTENTS}

Chapter

PAGE

I. The Sign of the Shell . . 1

II. How History May Be

TAUght . . . . . . . 11

III. Some Literary Gossip · . 21

IV. Spanish Point . . . . . 31

V. The Island Without Mark Twain. . . . . . . . 43

VI. The Return . . . . . . 55

VII. Battleships and Society • . 65 VIII. Mark Twain's Aquarium . . 75 IX. Odds and Ends . . . . . 85 X. The King and Kipling • . 93

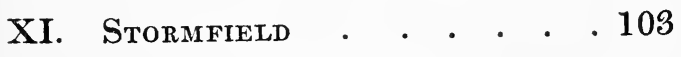
XII. Stormfield, Happily Continued • • • • • • 115 XIII. Letters . . . . . • . 127 



\section{ILLUSTRATIONS}

Mr. Clemens, Margaret, and Maude

PAGE

Frontispisc6

Out from under the shadows stepped a gray figure . . . . . . . . . 2

The great rambling hotel . . . . . . 4

They went in the donkey-cart . . . . 6

They jogged off down the road . . . . 12

The history lesson . . . . . . . . 14

The far end of the island . . . . . . 22

Past the quarry . . . . . . . . . 32

"I think a photograph is a most important document" . . . . . . . . . 34

The houses were startlingly white . . . 38

The sea dashed in spray upon the rocks . 40

Parting came all too soon . . . . . 44

An old wall lapped by the waves . . . 46

In the Botanical Gardens . . . . . . 48

Past the town . . . . . . . . . 50

His companion was Henry H. Rogers . . 56

Glances and cameras were always turned

upon them . . . . . . . . . . . . 60

The Chaplain's cousin . . . . . . . 66

They assumed a high moral attitude . . 70

His light weight could not discourage her . 76

The Angel-fish came into our circle . . 78 


\section{Illustrations}

Society that Mr. Clemens loved . . . . 80 A bit of the Happy Island . . . . . 86 Maude's expression was hard to catch . . 88

A house two or three centuries old . . . 94 Stormfield . . . . . . . . . . 104 It was hard to tell which he loved best . 116 "I want you to look at this view" . . . 128 "And watch the sun paint the waters". 138 
Ube 



\section{Mark Twain and the Happy Island}

\section{CHAP'TER I}

\section{THE SIGN OF THE SHELI.}

$7 \mathrm{NE}$ road to the hotel wound upward, and on either side of it palmettos rustled noisily beside still and somber cedars.

Out from under their shadows stepped a gray figure with a crown of glistening white hair. He walked lightly and looked about him with an air of interested and unconscious expectancy. As he came nearer the hotel veranda we recognized the shaggy eyebrows, the delicately arched nose, the drooping mustache. Indeed, we had realized his personality the first moment that his figure had emerged from the semi-tropical background. He could be no other than Mark Twain. He passed up the steps and into the hotel, his head held 
a little to one side, inquiringly. We heard a soft drawling voice for a moment and then a carriage clattered up to the veranda, bringing other guests, and we lost him.

For it was the day when the unsteady but regular steamer brought us, once in ten days, news and passengers from the world. Two weeks before, we, the Lady Mother and I, had crossed the stormy sea, a sea so stormy that the short voyage of forty-five hours seemed an eternity cutting us off from our previous existence. This feeling of finality had given a mysterious attraction to the green islands which rose gently out of the sea before us on the early morning of the third day. This, and the change from bleak and wintry December to glorious glowing summer, made us suspect that we were under the spell of some lovely enchantment. This suspicion became settled conviction as our boat, so pathetically small in the New York dock, suddenly loomed up into stately proportions as she picked her way through the treacherously smiling channel. She had a wary but important air as she turned and twisted between 


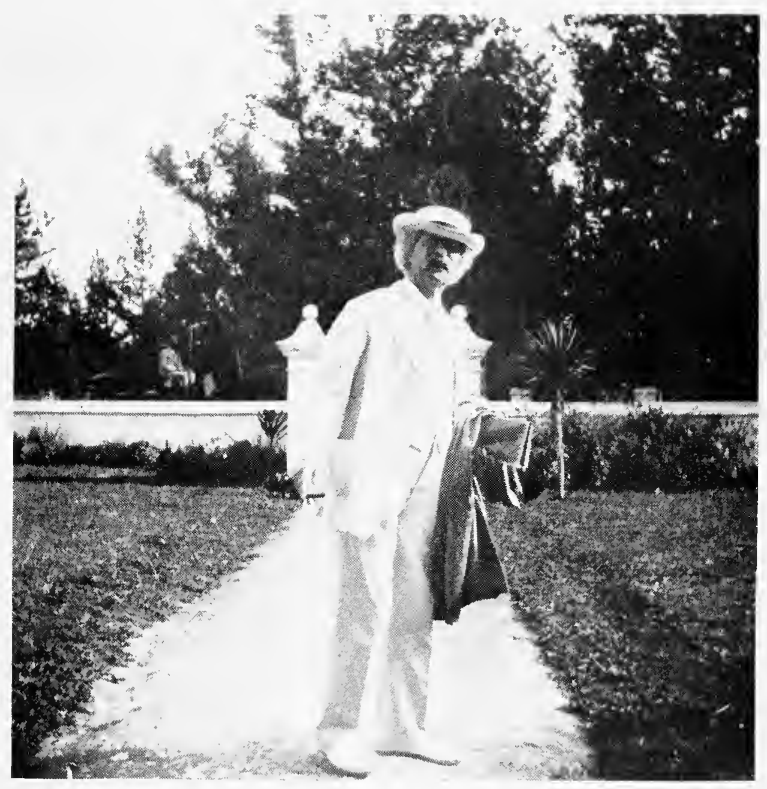

Out from under the shadow's stepped a gray figure 
$E$ 
the tiny islets, and then drew up majestically alongside the little wharf. And this conviction was deepened into happy acceptance when we drove over white coral roads, bordertd with palmettos and royal palms, when we saw banana groves and twenty-foot oleander hedges, when we breathed the fragrance of magnolias and caught glimpses of gleaming white houses through thick tropical foliage, and white roads winding up little hillsides, and when there flashed before us a dash of white spray.

There could be no doubt of it. A fairy had touched us with her magic wand, and we were again in the dreamy, happy days of the Golden Age.

The great rambling hotel which was to be our home stood half a mile from the dock and down close by the shore. It was the only large wooden building on the island, and that in itself was a distinction. Its long verandas looked out over the blue waters of the harbor, and sail-boats came clustering about the stone pier, hoping to tempt unwary guests.

Soon after coming to the Happy Island I 
found a companion and a playmate. It made little difference that Margaret's skirts were short and mine long, or that she wore her hair down and I wore mine up, and that she looked twelve years old while I only felt twelve. All this mattered little, for she had one of those understanding souls that knows with keen and sure intuition many things that others learn slowly and uncertainly. So she accepted me as her playmate, and we took long walks together, and exchanged confidences, and wove wonderful tales of magic and adventure and were quite content.

As a usual thing, Margaret and I felt but a languid interest in the passengers who came, for they did not invade our world. But on the morning that Mark Twain arrived, we felt an unusual thrill, and we wondered if we might not see him once in a while.

Until that day there had been very few guests, for it was the first of the year and the beginning of the season. But now the diningroom took on a distinctly populated appearance.

Margaret's table was not far from ours, 


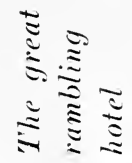

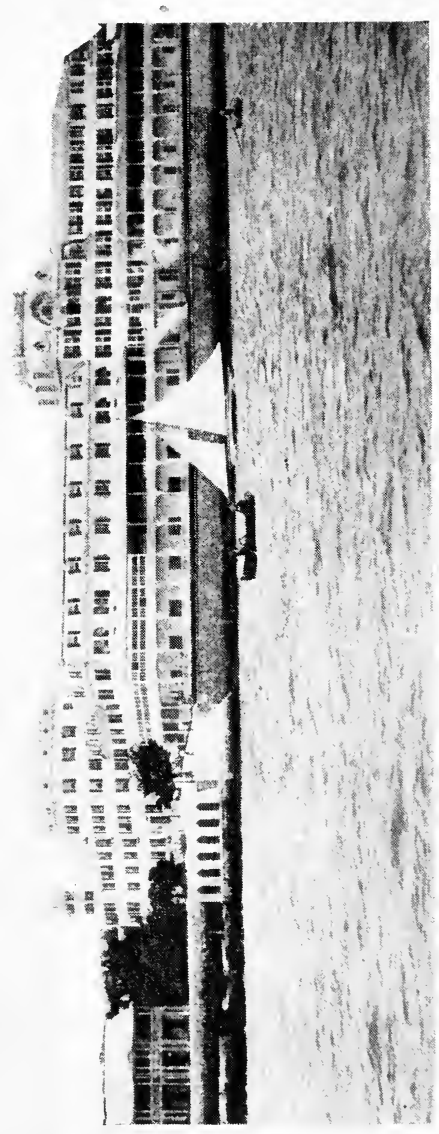




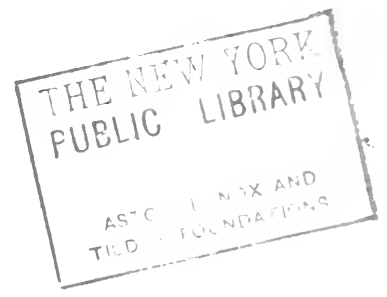


and that day she was sitting alone. Presently Mark Twain came in, and as he reached her table he stopped and spoke to her. He not only spoke to her, but had a conversation with her. I knew, then, that he had recognized her as one of the choice souls of the earth.

As soon as Margaret had finished her luncheon, she came over to our table, her sweet face beaming, and said: "That nice old gentleman is Mr. Clemens, and he is so funny. He pretended to know me, and he wants me to ride with him in the donkey-cart this afternoon, but I told him I had an engagement with you, and could n't go."

I told her I would release her from her engagement with me, for it was an honor to be invited to go with Mr. Clemens, an honor which she ought not lightly to forego. Then she told me in detail the conversation she had had with him.

He had said, after a moment of apparent hesitation, and in a tone of surprise, "Why, how do you do? I am very much ashamed of myself, but I believe I've forgotten your name." 
Margaret: How do you do? I'm afraid I don't know you.

Mr. Clemens (reproachfully): Have you forgotten me? I remember you very well. Your name is Janet.

Margaret: Oh, no, sir: It is n't Janet.

Mr. Clemens: I beg your pardon. I have a very bad memory. Oh! now it comes to me. You are Dorothy.

Margaret (entering into the spirit of the interview ): I'm afraid you have a bad memory, sir, a very bad one!

Mr. Clemens (undaunted): Now, that's too bad. I was sure I would remember - I think it must be - Margaret.

Margaret: Yes, that's my name.

Mr. Clemens: But I'm very much grieved that you should have forgotten me. I think you ought to have some sort of a memorandum of me, so that the next time we meet I should n't be subjected to the same humiliating experience. [Here Mr. Clemens took a little pink shell out of his pocket and gave half of it to Margaret.] Take this and guard it carefully, and every time we meet hence- 


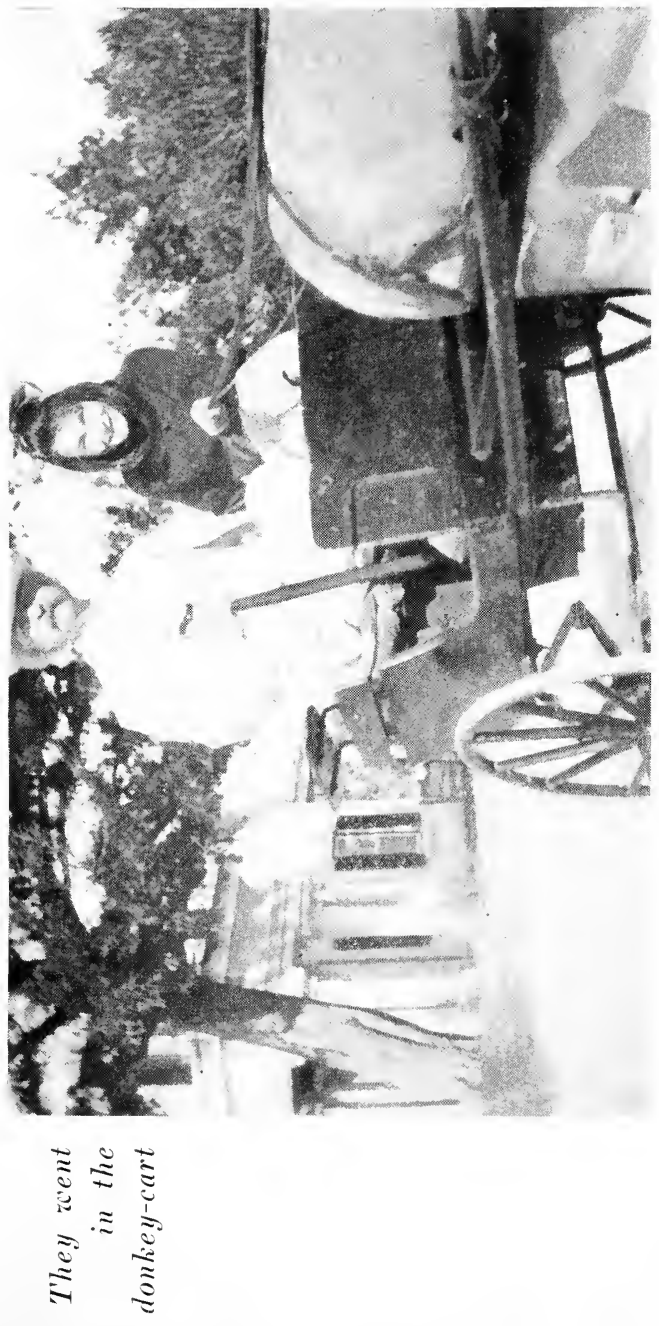



forward you can show me your half of the shell and I will show you mine, and if they match I shall know it's you and you will know it's I!

Of course Margaret gleefully agreed, and as proof she showed me her half of the shell, repeating appreciatively: "Is n't he a dear, funny man!"

And just here, although not in chronological order, I must relate the after-history of the divided shell.

Some time afterwards Mr. Clemens had two pretty gold-enameled replicas of the shells made, and he presented one of them to Margaret. The other he hung on his watch-fob.

Many months later Margaret went to visit Mr. Clemens in his Connecticut home. When the carriage drove up to the door Mr. Clemens was there to welcome his little friend, but Margaret looked at him gravely, hesitated a little, and then said: "Do you know if there is a nice old gentleman, by the name of Mr. Clemens, living here?" Mr. Clemens answered by drawing out his shell and showing it to her. She had hers in her hand. She 
compared them for a moment. Her face lighted up with a mischievous smile, and she ran into his outstretched arms, saying: "Why! you are Mr. Clemens!" 


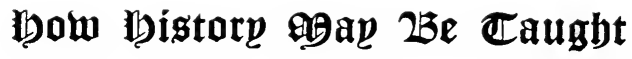





\section{CHAPTER II}

\section{HOW HISTORY MAY BE TAUGHT}

NHAT afternoon Margaret went with Mr. Clemens in the donkey-cart. I saw them start, or, rather, try to start. For Maude was stubborn and it took some time to persuade her to move. Maude was diminutive in size, but the amount of obstinacy she possessed would have fitted out a mastodon, nicely. She was always attached to a small cart, and early every morning she was at her post in front of the hotel. She showed perfect indifference as to whether she went or came. Of course, she preferred a stationary attitude.

Reginald was her guardian angel - a black little islander who enjoyed the distinction of being the only human being who could make Maude go. Later, Mr. Clemens discovered that he was also absolutely joke-proof.

As Mr. Clemens, Margaret, Reginald, and Maude finally jogged off down the road and 
disappeared at the turn, I felt a little lonely for my young playmate, and possibly a little envious. Why couldn't I, too, have been really twelve years old?

The next morning after breakfast Margaret's loyal soul could no longer endure the strain of divided affections. She brought Mr. Clemens over to me and said: "You must n't be rivals, and I want you to know each other." We said we would try to bury our hatred.

In the happy weeks that followed, the Mark Twain of Roughing It and of Innocents Abroad, of Tom Sawyer and of Huckleberry Finn, became Mr. Clemens of the Happy Island, and his companionship in gentle excursions, along peaceful, shady roads, was even more delectable than when he had led us over western plains or on European jaunts. In the delight of knowing Mr. Clemens we almost forgot Mark Twain. This charming, courteous gentleman, with the crown of silver hair, with his immaculate white clothes, his kindly deference of manner, his ready thoughtfulness, and his sweet affection for children, was sufficient in himself to win any- 



\section{How History May Be Taught 13}

one's heart, without the prestige of the other name.

I think it was the next morning after the meeting of the rivals that the history lessons began. We were at breakfast, and from our table I could see both Mr. Clemens and Margaret. I noticed Mr. Clemens writing for a while quite busily. Then he called the saturnine head waiter and gave him a card, with instructions. The unsmiling messenger took the card and carried it over to Margaret. She looked at it and nodded back smilingly at Mr. Clemens. The mystery was solved after breakfast when Margaret brought me the card, on which was inscribed her lesson in history. Mr. Clemens followed the pictorial method, and he used ingenious devices for fixing the length of a king's reign. For instance, on this particular card he wished to represent William the Conqueror. He had drawn a grotesque figure made with eleven legs and ten arms, which meant that he had reigned twenty-one years. Could there have been anything more lucid?

After breakfast, when he met Margaret, he 
asked her in his gentle drawl: "Margaret, how many arms and legs did William have?" Upon her replying promptly, "Twentyone!" he said, "Extraordinary, was n't it, dear? Extraordinary!"

These history lessons continued with regularity, to our great delight. I remember that Stephen was a huge foot with nineteen toes. Henry II was a head with a mouth made like this: \$-35-\$. Richard the Lion Hearted was a lion. Half of him was drawn on one side of the card, with " over" written underneath, and on the reverse sprawled the last half of him. In his mouth was a heart, and, dangling from it, a card bearing the dates 1180-1199.

The dining-room was a large light room overlooking the sea. The meals were leisurely to the last degree, and it was a very nice place in which to make informal calls. Mr. Clemens was rather abstemious, and when he had finished earlier than the rest of us he would often come over to our table and talk. His whimsical way of putting things, his deep knowledge of human nature, his half-pessimis- 


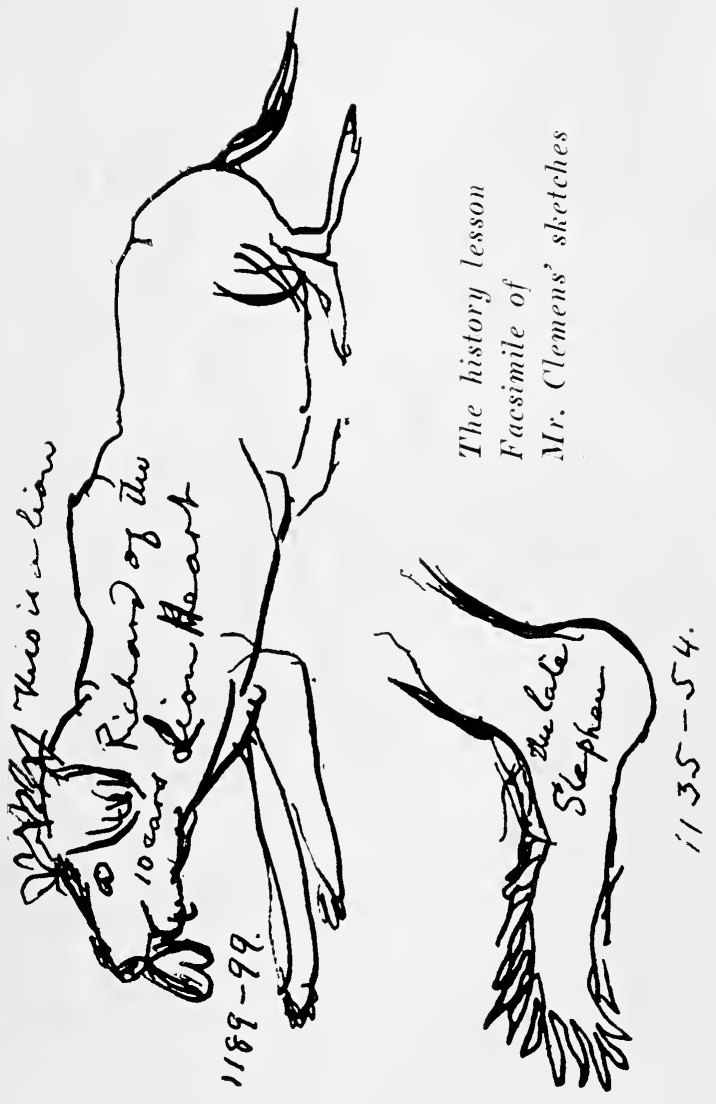





\section{How History May Be Taught 15}

tic philosophy, his kindly toleration, in most things, made everything he said so precious that we did not want to lose a word. The morning after we had heard of the assassination of the King and the Crown Prince of Portugal he came over and sat down, and the conversation naturally turned on that topic. " Did you ever realize," he said, " how awfully difficult it is to kill a king? Think how many times it has been tried, and how often it fails! They tried it eighteen times on Henry IV, many times on Queen Victoria, and we don't know how many countless times on the Emperor of Russia. Will those anarchists never learn that when the heart is filled with hate the hand that aims the weapon will surely tremble!"

From this we went on to speak of certain common traits of the human race, and Mr. Clemens launched forth on a tirade against the general asininity of us all. Hysterical hero-worship and the fickleness of public favor were touched upon. Mr. Clemens grew eloquent and took as a symbol a temporary triumphal arch-one built for a popular 
hero. "It was made of staff and plaster because the people hadn't time, they hadn't time [I can still hear the insistent nasal drawl which gave such a world of meaning to these words] to build a more enduring token. They would build it in marble, later-yes, later, when they had more time! The plaster arch crumbled away, but later, when they had time, there was no hero to whom to build the enduring arch."

We happened to mention the description of the Bander-log in the Jungle Book as one of the best satires ever written on the human race. This gave Mr. Clemens another text, upon which he grew wonderfully eloquent. Yes, we were all Bander-log, and the biggest Bander-log of all was whoever sat in the executive chair of the nation. $\mathrm{He}$ wondered why the Almighty had ever created us. It was bad enough to have concocted the house-fly, or to have imagined rats and mice, but the Bander-log was the crowning mistake. And then, to conceive of the idea that this same Almighty who had created us wanted to have our company through all eternity! $\mathrm{He}$ 
laughed gently as he finished his blasphemous tirade, and, looking at the Lady Mother, who wore a slightly puzzled expression, he added: "Now, you must forget all that I've said, and if the Recording Angel brings this up against me I shall simply tell him that I never said anything of the sort, that it was those $\mathrm{W} \longrightarrow \mathrm{s}$ who were talking!" 



\section{Gome Literary Gossíp}





\section{CHAP'TER III}

\section{SOME LITERARY GOSSIP}

NCE in a while it rained on the Happy Island, and when it did, it did it thoroughly. The water came down in sheets and torrents, sweeping in from the sea, across the harbor, blotting out the islands and filling the air indoors with moisture. At such times it was impossible to brave the weather, for the most impermeable protection became soaked. One compensation, however, was, that the instant the rain ceased, the hard, white coral roads were as passable as ever. You could walk out, holding your head high, and with no fear of bringing up in a mud puddle.

One Sunday morning the weather was thus comporting itself, and it was hard to mark the dividing line between sea and rain-drenched atmosphere. We went out on the veranda, where we found a protected spot and some capacious chairs. Margaret had been con- 
demned to write letters, and Mr. Clemens missed her. He came out on the veranda and joined us. He was dressed, as he always was in daytime the last few years of his life, in white serge. The only color about him was the dark brown of a row of cigars in either breast-pocket. The row diminished as the morning progressed. He was always inmaculate, although he wore his clothes easily, and there was never anything about him to suggest that he himself cared how he looked. His beautiful white hair curled softly in the dampness, and he was the image of picturesque comfort as he pulled at his cigar and talked.

It may have been the suggestion of the day, but, whatever it was, something moved him to discuss missionaries. This subject, together with old-fashioned orthodoxy, were topics that invariably stirred him to satiric loquacity. He gave the poor missionaries no quarter, he made no exceptions, they were all impaled upon the sharp brochette of his keen diction and grilled by the fire of his contempt. And all that he said, he said in his quiet slow drawl, with a twinkle of the eye, once in a 


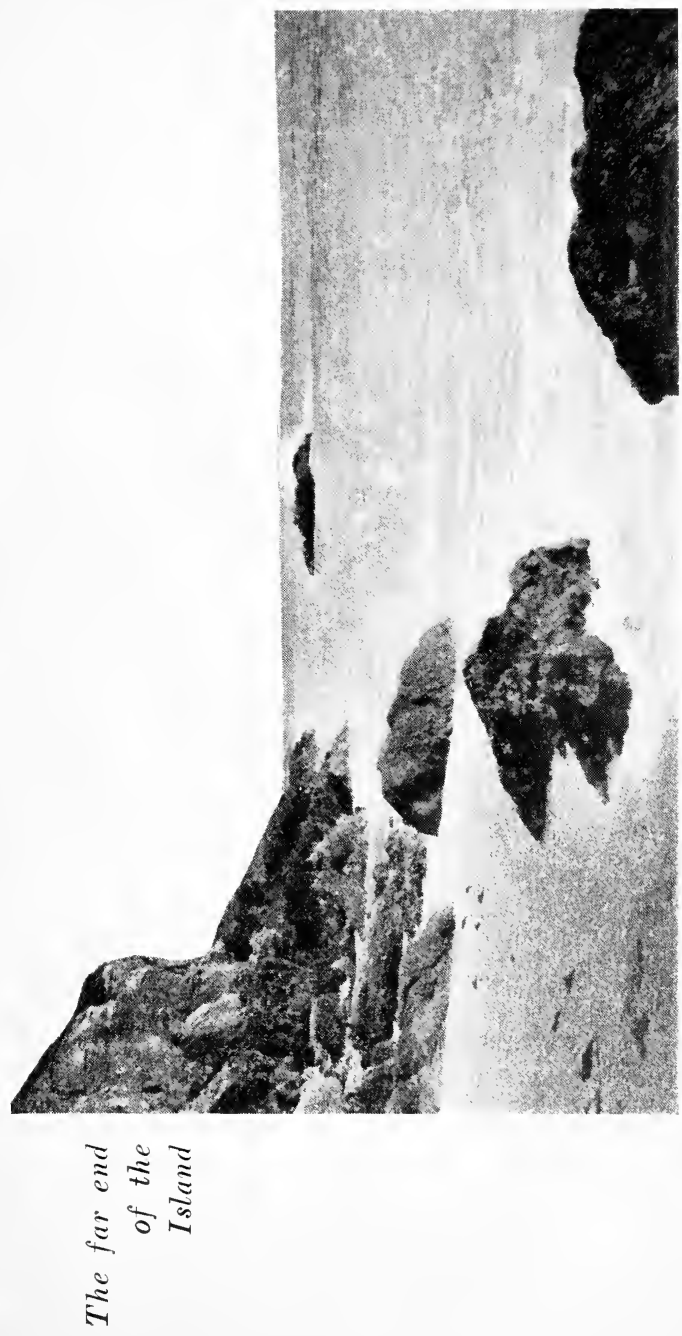



while - a twinkle that one did not often see, unless one looked carefully, for his bushy eyebrows almost concealed the deep graygreen eyes. He often made us wait for a word, but when it came it was the only one in the Century Dictionary that could so exactly have conveyed to us what he wanted to say.

There sat not far from us a sweet soul whose heart was deeply interested in the missionary cause. All unconscious of this, Mr. Clemens went on. A long time afterward he learned that she had overheard the conversation and the quick expression of his regret showed that his kind heart saw no humor in that situation.

After an exhaustive arraignment of missionaries and their weaknesses, something was said about Mr. Clemens's recent story of "Captain Stormfield's Heavenly Experiences," which had shortly before appeared in magazine form. Mr. Clemens chuckled as he asked us if we remembered the picture of Heaven as presented in Elizabeth Stuart Phelps's book, Gates Ajar. He said that 
when he read that book he was deeply impressed by what seemed a sentimental and foolish idea. He resolved to satirize it, and wrote the first draught of Captain Stormfield. The result did not quite suit him, and, besides, he hesitated to publish it so soon after the appearance of Miss Phelps's book. So he put the manuscript aside, and it was almost forgotten. Then one day he came across it, thought it worth publishing, and sent it to the magazine where it appeared.

His cigars were not all smoked, and the rain continued to fall prodigiously and so we led him on to talk of other books he had written. One that he loved best of all, perhaps, and that is not nearly so widely read as his others, was Personal Recollections of Joan of Arc. He said that for years he had been impressed by the spirit of the French heroine, and year by year, for twelve years, he had laid by in his memory, and in his notes, every impression he could get of her. The most thrilling historical document he had ever read, he said, was the official account of her trial. And he regretted that he had not traveled in the 
parts of France where she had lived. Finally the time came when he could write of her, and he found that she stood forth in his mind, a clear, convincing figure.

There was a silence as he finished speaking of her, and we looked almost reverently on this man, who had seen into the heart of a simple peasant maid, and had understood the inspiration that had transformed her into the savior of France, and yet had kept her girlishly gay and womanly sweet.

The silence was broken by Mr. Clemens, who said, whimsically: "My books are really exceedingly serious and have been made the subject of profound study." He then told us, with much relish and some elaboration, the history of the Mark Twain Club.

One day he had received a communication from the north of England. The letter was written on heavily embossed and crested paper, and was to the effect that a club had been organized for the purpose of studying the works of the great American humorist. The writer delicately hinted that this had not yet been done in a scholarly and scientific manner, 
and that it was the intention of the Club to delve deeply into the stores of philosophic wisdom which were sometimes hidden from the casual reader by the super-fabric of wit and humor. The organization, with the permission of Mr. Clemens, should be known as The Mark Troain Club, and would feel itself much honored if it might send the record of its proceedings to Mr. Clemens.

Mr. Clemens was pleased, very much pleased. His works had not received the attention from scholars and from learned societies that he felt they deserved. Now justice would be done them.

With some pardonable degree of complacency he received and read the first papers of The Mark Troain Club. They were most satisfactory. The Club had printed not only the record of proceedings, but also the studies presented. From time to time Mr. Clemens received these reports. The society was evidently flourishing. A letter came from the President saying that the Club had decided to have an emblem; that, after much thought and consideration, a suitable design had been 
chosen, and that they begged Mr. Clemens to do them the honor of accepting one. A few days later a small box arrived containing a very beautiful and curiously wrought pin set with a number of precious stones. Mr. Clemens took great pleasure in wearing the pin and in carelessly saying to inquiring friends: "Oh, yes! that's the pin of The Mark Train $C l u b$, an English organization.- Yes, it's very interesting."

After some time the publications of The Mark Twain Club ceased to come, and the incident began to lose some of its vividness.

When Mr. Clemens was making his lecture tour around the world, a fine-looking gentleman approached him at Sydney, Australia, after his lecture, and said: "Mr. Clemens, I am Sir — , the President of The Mark Treain Club. It would give me great pleasure if you would take supper with me. I could then give you some interesting details regarding the Club."

Mr. Clemens accepted, with pleasurable curiosity. When they were seated at table the Englishman leaned over and said, in a 
confidential tone, "I am The Mark Twain Club." He then went on to explain that some time before he had suffered from a nervous breakdown and, while in that condition, he was ordered by his physician to abstain entirely from all mental excitement. He had thereupon retired to his estate in the north of England and, while there, had conceived of the happy idea of the Club, as furnishing a mild distraction without any attendant mental strain. He was the charter member. There had never been any others.

"But the pins?" queried Mr. Clemens.

"You are wearing the only one that was ever made," replied the courteous founder of The Mark Twain Club. 


\section{Spanisb 1⿴oint}





\section{CHAP'TER IV}

\section{SPANISH POINT}

NE brilliant Sunday afternoon we went to Spanish Point. When Mr. Clemens, Maude, Reginald, and one or two others went, there was always a preliminary animated discussion as to who should ride. Maude, obviously, could n't. Reginald, offcially, could not. It was an open question, never quite settled, as to which was the more strenuous exercise, urging the reluctant Maude to go, or tramping alongside trying to keep her slow pace. Sometimes we would toss a penny and abide by its fall, or Mr. Clemens would gravely refer the decision to Margaret, as the most serious of the party. Then the two destined to the more vigorous work entered the cart and moved off down the road and up the hill past the quarry, on the way to Spanish Point, two miles away.

The shell road, smooth and hard, was bordered on either side by mossy stone walls. 
Over these walls hung the beautiful purple vines of the bougainvillea, heather with its small scarlet flower, or yellow clusters of the pigeon-berry. Sometimes the stone wall stopped and a hedge of the variegated matchus-if-you-can took its place, behind which rose the hectic blossoms of the hibiscus. Here and there drooped a grove of palms where bananas clustered thickly on the branches, and then tall cocoanut trees swept up to greater heights. Just beyond a grove of sweet-scented cedars a hospitable gateway broke the wall. It bore an attractive legend, like Norwood, or Soncy, or Olive 'Iill, and a driveway fringed by a marvelous tropic growth led windingly to some big, low, white coral-stone house, overrun with veranda-roses and all sorts of sweet perfumed flowers.

The air was limpid and soft, the houses were startlingly white, and the brilliant foliage led a reckless and vivid existence on either side of the imperturbably hard and dry road. Sometimes we would stop suddenly at the clear, sweet notes of a cardinal bird and catch a glimpse of his scarlet coat against the deep 

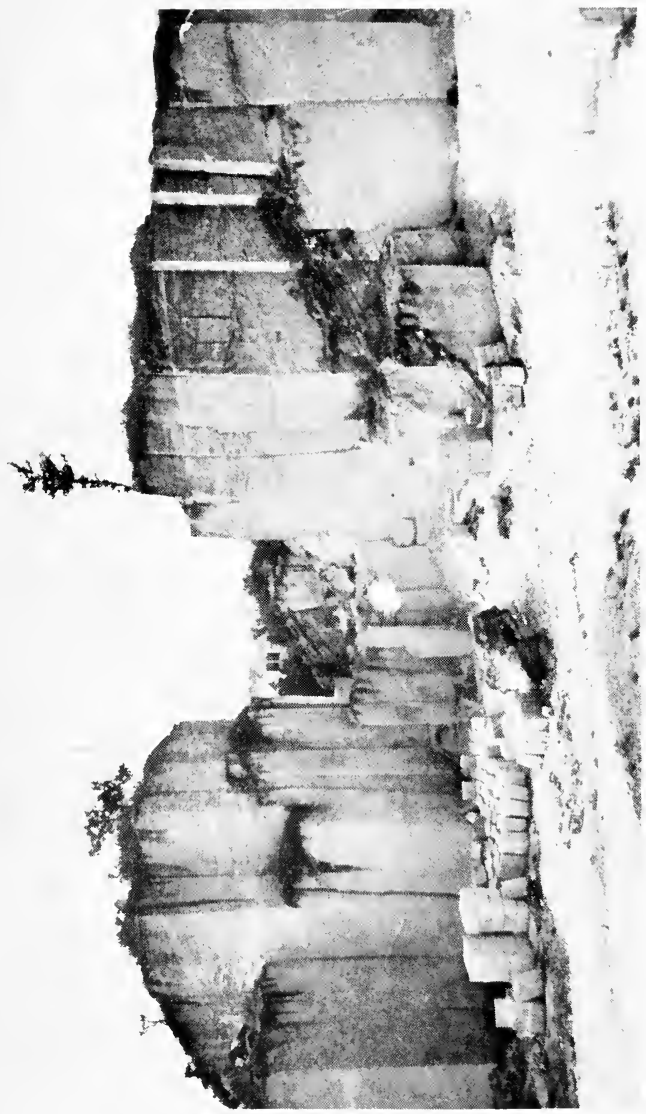

言 

green of the cedar. Sometimes we would look out between the trees to the blue glimmer of the harbor, where sails looked like white clouds as they flitted past.

Mr. Clemens was in a particularly happy and reminiscent mood; but when $I$ try to put down what he said I feel that it lacks the pungency of the sea air and the charm of his drawl.

Mr. Clemens was more often serious than humorous in conversation, and I never knew him to be funny for the mere sake of being funny. He never seemed to say anything to win applause or to evoke laughter. If he said a humorous thing, it had to be humorous enough to satisfy his own sense of humor. It must not fall below his own ideal. I never knew him to say a clever thing at the sacrifice of a kind thing, nor a witty thing divorced from truth. I don't mean mere vulgar facts, but truth, truth about human nature - he was always true to that.

We had scarcely lost the hotel from view when we met a group of gentlemen, evidently tourists. One of them came eagerly up to us 
and, accosting Mr. Clemens, said: "I beg your pardon, Mr. Clemens, but my daughter is particularly fond of your writings. Would you object if I took a picture of you for her?" Mr. Clemens, who chanced to be walking at that particular moment, answered immediately: "Certainly not, sir. Where do you wish me to stand?" The man became so nervous that he could n't snap his kodak and handed it to his companion, exclaiming: "Say, you take it! I guess you can manage it better than I can."

As we passed on we asked Mr. Clemens if he did n't ever get tired of being bothered in this way, but he replied that it was very little trouble to stop for a moment, and was most gratifying to his vanity! I had noticed that Mr. Clemens always assumed a dignified pose at such times, with a serious, almost severe expression of face. When he was spoken to of this he said: "I think a photograph is a most important document, and there is nothing more damning to go down to posterity than a silly, foolish smile caught and fixed forever." 


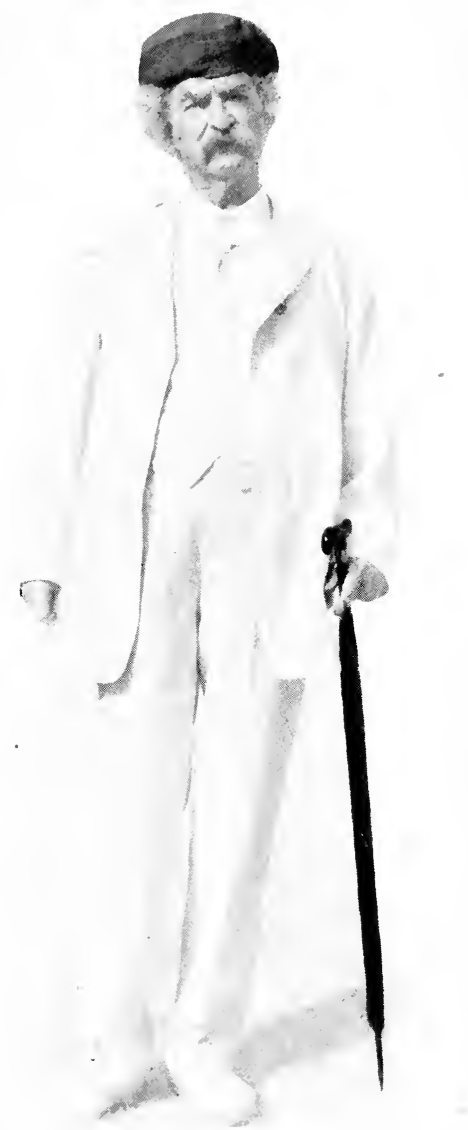

"I think a photograph is

a most important document" 
1 
Mr. Clemens had presented me the day before with a precious volume which he had discovered in the island book store, entitled Beeton's Complete Letter-Writer for Gentlemen. It had appealed to Mr. Clemens's sense of humor. He had written this inscription on the blank page, "To Young Lady desirous of perfecting Herself in the Epistolary Art [date in full]. Dear Miss - Try Beeton, Trust Beeton, Beeton is your friend. Have no fear. Sincerely yours, S. L. Clemens." This choice book we carried with us and regaled ourselves, from time to time, with particularly rare specimens of the epistolary art.

Apropos of this book Mr. Clemens told a story he remembered from his boyhood, of a negro who was up north and who wanted to communicate with his mother down south. $\mathrm{He}$ went to his mistress with a Complete LetterWriter in his hand, having selected therefrom a model entitled: "From a Young Man proposing marriage to the Lady of His Choice." He insisted upon his mistress copying this verbatim. Protests were in vain, and she was 
obliged to reproduce the ardent but utterly inappropriate words. She learned months afterward that the letter had had an enormous success, and that all the darkies on the plantation had tried to emulate this effort. The mother was pleased beyond words, and the letter became an authority to be consulted by everyone, no matter to whom or about what he was writing.

This story led us to talk of life and its disappointments. Mr. Clemens advanced a favorite theory: "If I had been helping the Almighty in his job I would have commenced at the other end, and have the human race begin with old age. It would have been infinitely better and more logical to begin as old men, and have all our woes and aches and troubles over in a few years. They would be much easier to bear sustained by the hope of a joyful youth. And think of the exhilaration and inspiration of reaching eighteen and knowing that you were never to be old and wrinkled again. Yes, the Almighty made a pretty bad job of it, pretty bad!" 
By this time Maude's pace, which had gradually been growing more languid, stopped altogether, and we decided to rest a while by the roadside. Across the road was a house two or three centuries old. It had evidently not been whitewashed for years, and had become a beautiful soft gray. It reminded us of Old England, whence its first owners had doubtless come, and we asked Mr. Clemens to tell us of some of his summer experiences on the British Isles.

Although the experience of the previous summer, when the Oxford degree had been conferred upon him, had probably been the culminating one of his life, he very seldom spoke of its events or referred in any way to the wonderful homage he had everywhere received. So when we asked him he replied: "There was one incident that may amuse you as it did me. It was on the occasion of the Open Air Pageant at Oxford. I had been detained and came in a little late, with Lord Curzon and Rudyard Kipling. We were conducted to a box, and, when seated, a note was. 
passed to us - a little slip of paper on which was written, 'Not true.' Upon opening the paper, we found inside these lines of Kipling:

"East is East and West is West And never the Troain shall meet."

As he finished the story, he added: "By the way, the best picture I ever had taken was at that time. We were coming out in procession, and I was walking beside Sidney Lee. Mr. Kipling was behind me, and someone with a camera tried to snap him; but the kodak slipped, or something happened, and it turned out that I had eclipsed him completely, and there was nothing left but the tip of his ear."

Maude was now sufficiently rested, and we got up to jog along to Spanish Point. The sea was very beautiful and dashed in spray upon the rocks. We gathered shells and polished pebbles, and wrote names in the sand, and then turned to come back.

Mr. Clemens talked of his father and of the latter's attitude toward the slave trade. He told us with much chuckling of the time he took his mother to a minstrel show, having deluded her into the belief that she was going 


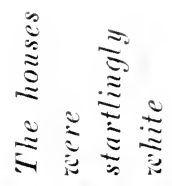

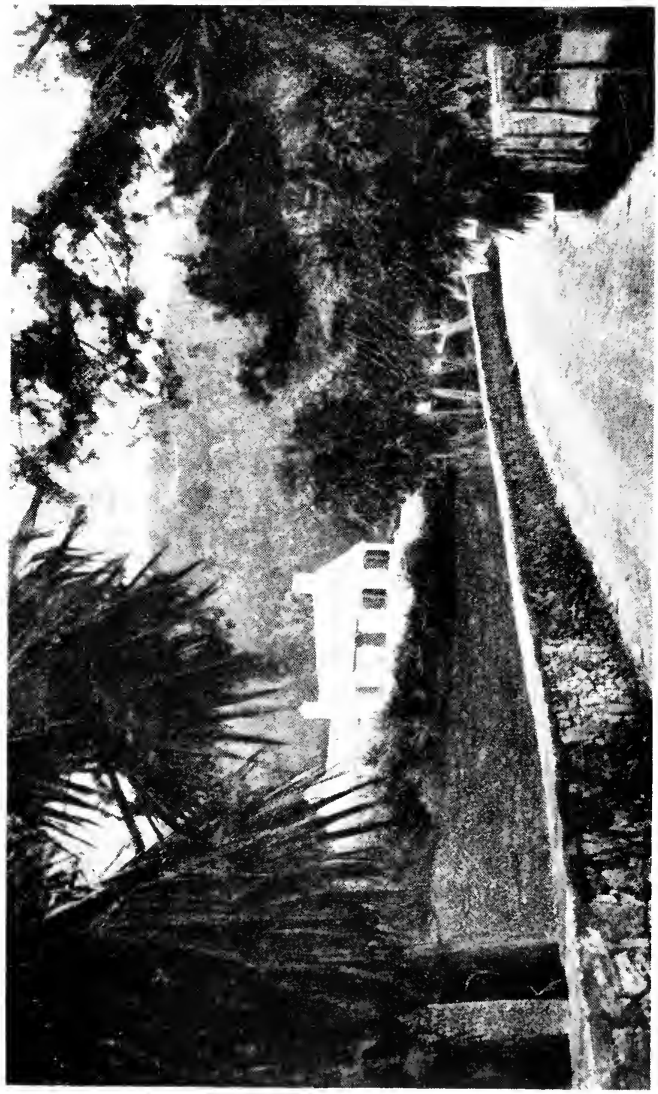


<smiles>C1=C2CCC(CCCC1)C2</smiles> 
to hear some African missionaries. And that reminded him of a later incident, which he related thus: "I haven't told you of the time I was asked to address John D. Rockefeller Jr.'s Sunday-school class, have I? Well, once John D. Jr. sent me an invitation to talk to his class on any subject I might choose, taken from the Bible. Just before this time John D. Jr. had been whitewashing Joseph a good deal, and making him out to be a pretty fine fellow. So when the letter came with this invitation I said to my secretary: 'You just write to Mr. Rockefeller that the only subject that seems to interest me very much just now is the subject of Joseph, but that I'm afraid that what I have to say about him won't exactly meet with his views.' This was written to him, and by the next mail came a very polite answer from Mr. Rockefeller saying that he was sure that anything I would have to say would be most profitable, but that perhaps it would be advisable for me to jot down my thoughts and send them to him beforehand. I followed his happy suggestion, and I exposed Joseph in a way he 
had never been exposed before, and I said what I thought of his whole Egyptian policy in perfectly plain terms. It was really very good," and Mr. Clemens gave a reminiscent chuckle. "I sent the manuscript on to Mr. Rockefeller, and, do you know, he never pursued the subject!"

Maude realized the nearness of home and food and mended her pace. Margaret exclaimed gleefully: "Oh, Mr. Clemens! She's going, she's trotting!" And with a triumphant wave of the whip, they left us behind and we heard no more stories that afternoon. 


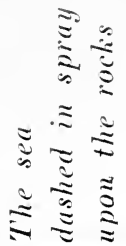

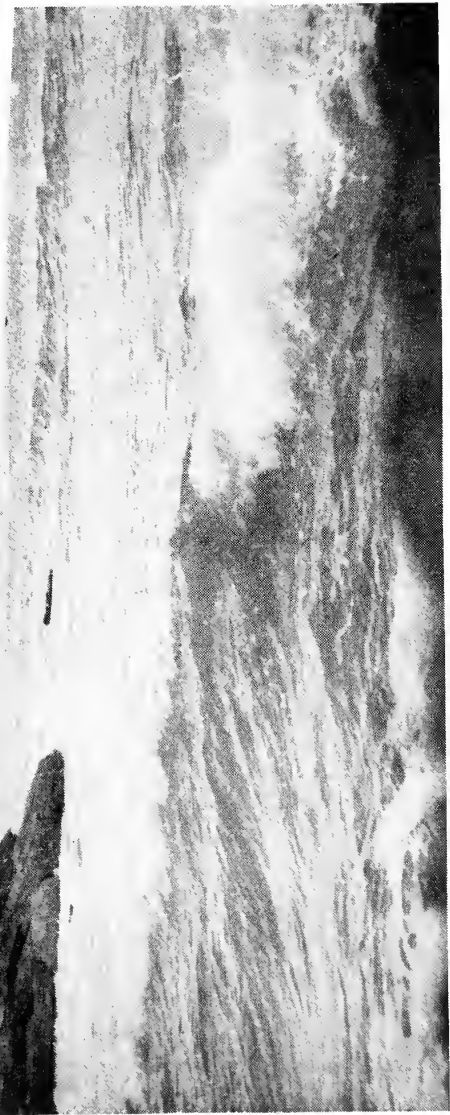




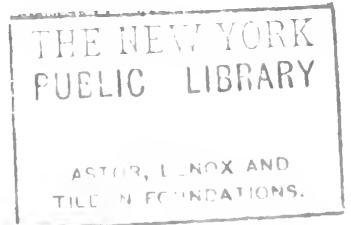


Cbe Island witbout $\mathfrak{G a r k} \mathbb{C} \mathfrak{T a i n}$ 



\section{CHAPTER V}

THE ISLAND WITHOUT MARK TWAIN

NHE time of parting came all too soon. Mr. Clemens had to be back in New York to be host at a very special luncheon, and Margaret had to submit to some educational discipline which we privately decided she could easily get along without. However, parental prejudices have to be considered, and we had to bow to the inevitable.

The day before they sailed, Margaret said to me, "Is there a Mrs. Clemens in New York?" I told her that Mrs. Clemens had gone very far away and would never come back. "Has Mr. Clemens any little girls?" pursued Margaret. I answered that his girls were now big girls, but that he had lost one whom he now remembered as his little girl, and whom he had loved very tenderly, and that this was the reason he loved other little girls so much. It made him less lonely when 
he had them about him. Margaret thought for a moment; then, her brown eyes full of tenderness, "I wish $I$ was Mrs. Clemens, and then I would just care for him and care for him, and love him awfully!"

Margaret felt for him the deep affection that children have for an older person who understands them and treats them with respect. Mr. Clemens never talked down to her, but considered her opinions with a sweet dignity. This wonderful comprehension that he had of children, and his perfect sympathy for them, helped us to understand better the simplicity of his own character. When we were with him, we, too, felt like little children. All pretentious wisdom, all sophisticated phrases, all acquired and meaningless conventions were laid aside, and we said what we meant, and spontaneity took the place of calculation, and we became simple and unafraid, and sure of being understood.

We went down to the boat to say good-by to Margaret and Mr. Clemens. The latter, however, hated farewells of any kind, and so he went directly to his cabin and did not 


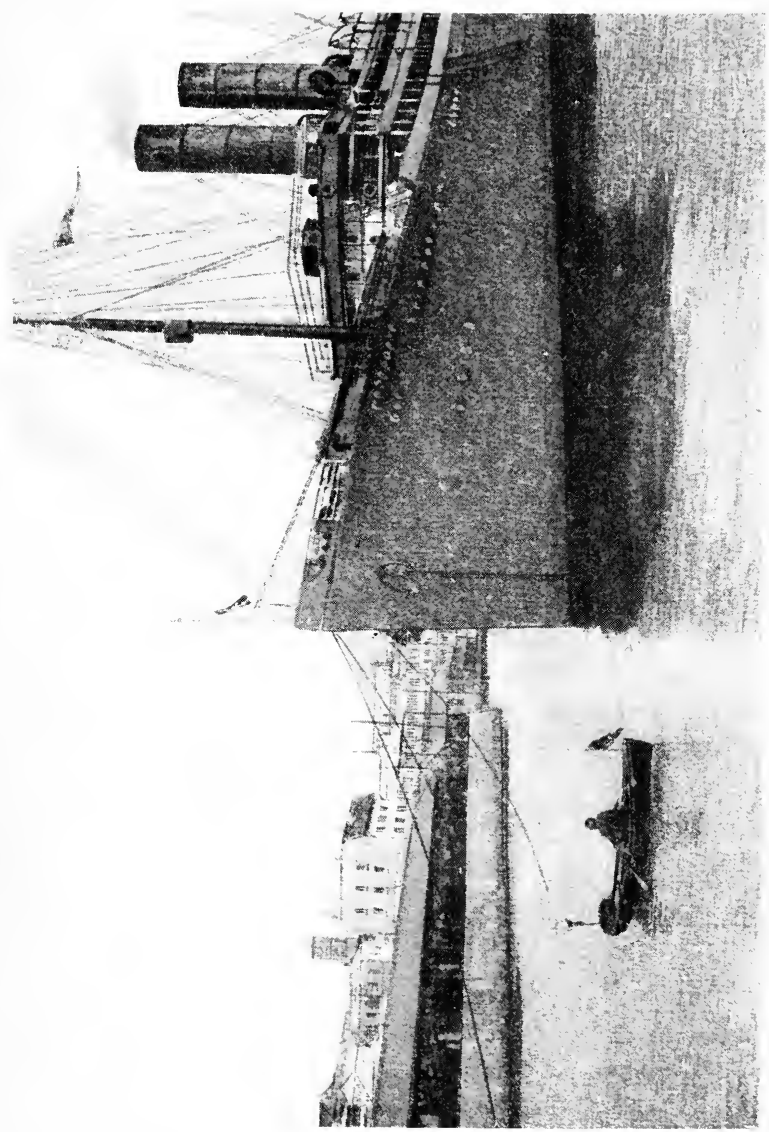

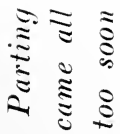



emerge therefrom until they had lifted anchor.

As the ship sailed away bearing the sweet little girl, Margaret, and the sweet old man, Mr. Clemens, we felt that the island had grown suddenly smaller, that the colors had faded, and that there was a chill in the air. As we turned away from the dock, however, we saw the familiar form of Maude, standing quiet, imperturbable, unmoved by any emotion, and we felt comforted.

Mr. Clemens had not cared for sailing, so when he had gone we thought to distract our minds by this. Neither was the Lady Mother fond of this particular amusement. The next morning after the steamer went away, I suggested to her that we take a sail. She was examining the interior of a sago-palm at that moment, but she heard my wild proposition. She looked at me pityingly and said: "I want to enjoy my stay here."

She had been inveigled into a rowboat one day. She stepped into it gingerly, and then sat in rigid misery for nearly an hour, eyeing with distrust the other craft in the harbor, 
for she attributed to them all a sinister intention of running us down. So she was not to be persuaded.

However, a companion was found, and we went down to the pier where the boats stand waiting for customers. The skippers are haughty men who do not beg for patronage. In this they have a social standing far above that of the rowboat men, who shamelessly clamor for passengers.

We took the blackest skipper we could find. $\mathrm{He}$ was big and muscular and passing homely, but he had a settled gravity that won our confidence immediately. He seemed to regard with some disdain our order to sail among the islands, so that we might take pictures. His disdain grew into a withering contempt when our taste in subjects was revealed. He suggested a big new house that stared unblinkingly out on the view. When we showed no appreciation he grew silent and taciturn and eyed us with suspicion from time to time. All interest in us died out, and he seemed to grow deaf and dumb when we asked him to go near an old wall lapped by the 


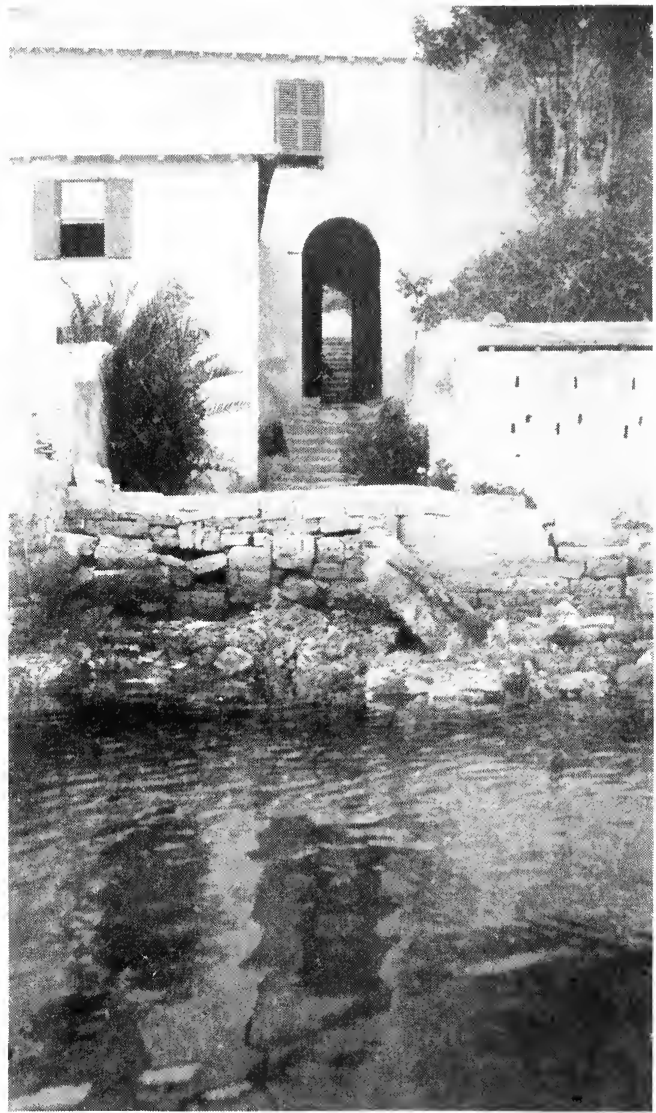

An old wall lapped by the waress 

waves, where cedars and oleanders grew, and where the naked, lace-like branches of a Pride-of-India tree were outlined against the sky. Only once did he vouchsafe to talk, and that was when we had beguiled him to tell us about the Boer prisoners. "Yes, they used to be on that island. They lived in tents and had good things to eat. The men were on one island, the boys on another, and the hospital over there on still another. They were very religious, and every afternoon at five you could hear them singing hymns." "Did any one ever try to escape?" we queried. " $\mathrm{Oh}$, yessum; several. There was one who cut down a cedar tree one night and threw it into the water, then jumped in himself, thrust his head up through the branches, and swam slowly down to the hotel. He was an officer, and had it all arranged with his friends who were stopping at the hotel. They gave him clothes and took care of him that night, and the next morning he went on board the steamer like any ordinary passenger, and so got to New York. There was another poor fellow who wasn't so successful. He took a 
box and cut air-holes in it, and used that for a head covering while he swam out towards an American ship. As bad luck would have it, a sailor who knew a bit about tides saw this box apparently floating out, while the tide was coming in. He thought there was something mighty queer about that, and he sailed up alongside. The Boer was taken again." "And what happened to him?" "He was shot, madam."

Our skipper was actually growing garrulous. We were fascinated, not only by his stories, but by his language. It seemed strange to hear a black, black negro speak with an English accent and use almost elegant phraseology. The first time I had been impressed by this characteristic of the black people of the island was when, a day or two after our arrival, we had gone to the Botanical Gardens. Seeing a very strange-looking tree, I asked a darkey who was working near by, what the name of it was. He replied instantly with a rather long and complicated name, which I did not quite catch. I said, "Is that its botanical name?" To which the 


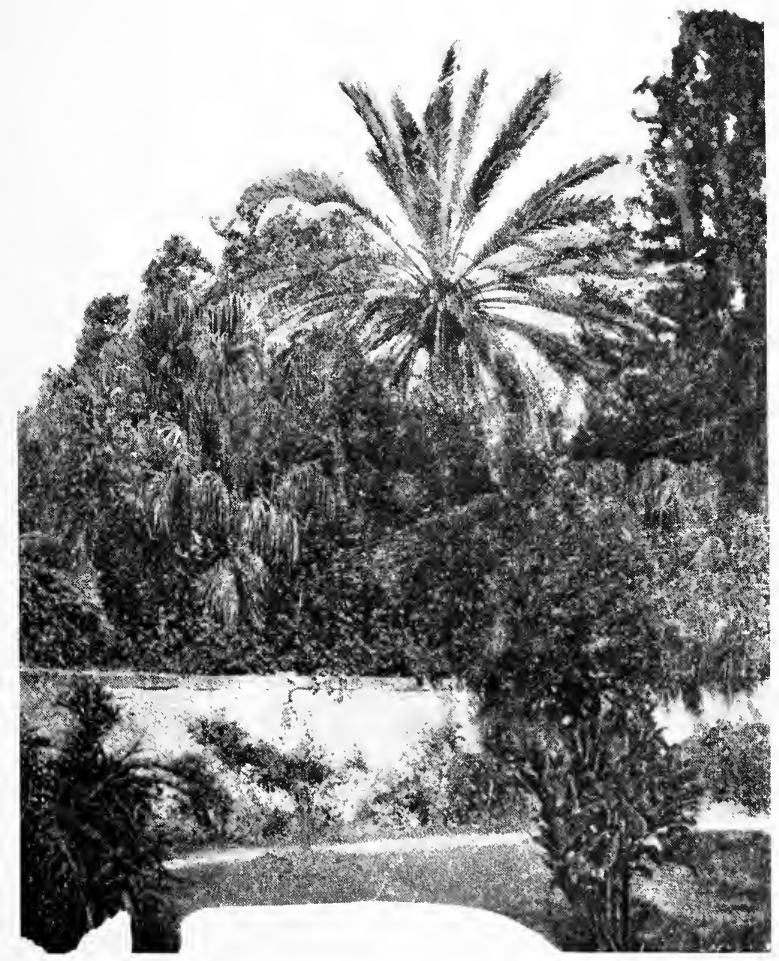

In the Botanical Gardens 


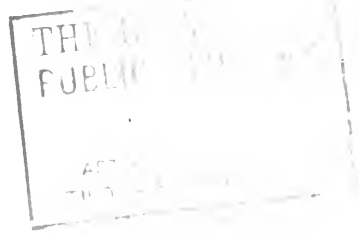


dusky gentleman answered: "Well, madam, to a certain extent it is."

When the lunch hour made itself felt we gave the word to go home, and our skipper made a good landing at the pier, where other boats had already come in. Others followed, sails were lowered, and soon there were half a dozen or more clustering about the stone landing, their slender masts outlined gracefully against the sky. The wind went down as though it, too, needed a siesta, and the sky began to veil itself in soft gray clouds.

The moonlight nights were very clear and beautiful, and when by chance there was a breeze, just enough to ruffle the surface of the water and to fill the sails, and when there was a softness in the air, then we would go out after dinner. And as I think of it now I re-live the scene. As we go down to the pier our voices ring clear in the still air. The bumping of the boat against the wall echoes with a hollow sound - the song of a lonely oarsman in a distant boat comes distinctly over the water.

We get in and tuck the steamer rugs about 
us, and in a minute a breeze catches us, the boat bends to it, its bow cutting through the dark water with a gleam of white foam. Above us the stars shine, some large and still, with steady yellow light, others far away and cold, and others twinkling uncertainly, but with a friendly, familiar air, as if to say, "We, too, are small and unsure of our existence." We sail down the harbor, past the town, where lights are gleaming from the windows of white houses, and the hills beyond show little twinkling stars of light through the black of the cedars. The rival hotel has lights streaming from every window, and we can hear the broken strains of a two-step, which sound like the intermittent efforts of a lame man to dance.

Tied up to a wharf is the Halifax steamer, getting ready to sail at midnight for the West Indies. Slender fingers of yellow light point from its portholes, the donkey engine creaks dolorously, and melodious darkey voices are heard singing out orders. We pass over the wavering reflections in the water, and, catching a stronger breeze, we sail out into the 
气ั

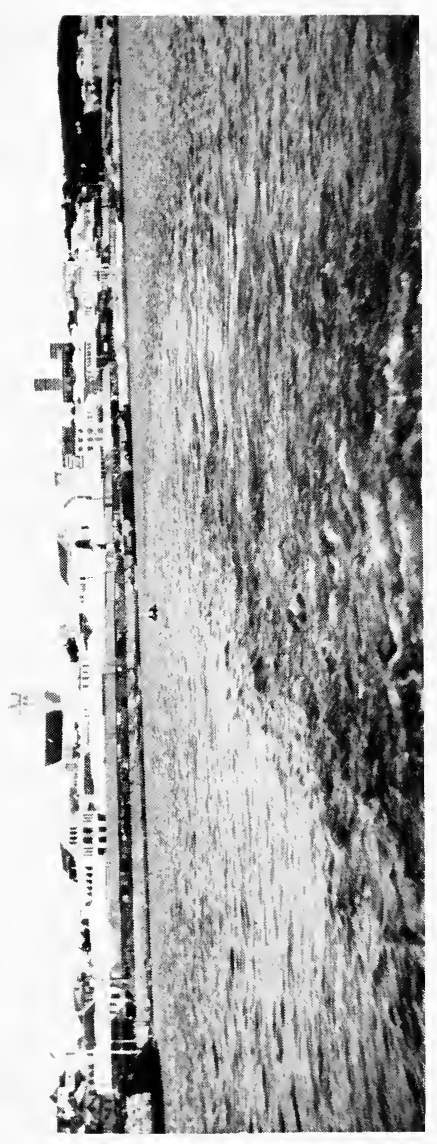




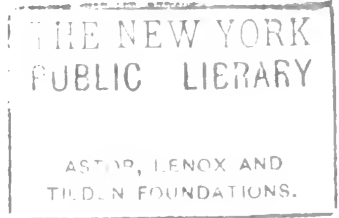


larger harbor, where the emerald islands look black against the steely water. Clouds have come across the moon, clouds that hint at storms, but there is still a silver path down to our boat.

We grow silent, for the beauty of the scene enters into our hearts, and night is voiceless and needs no empty words to sing its praises. Our boat glides along, with scarcely the sound of a ripple. The sail is black against the sky, and we are borne to the mystic land of night and dreams, down the silvery path of moonbeams. 



\section{Tbe Return}





\section{CHAPTER VI}

\section{THE RETURN}

तHE Happy Island was only two weeks without Mr. Clemens, after all, and our hearts were filled with joy when his return was announced. This time he came to stay for a longer period. His companion was Mr. Henry H. Rogers, a tall, distinguished looking man, with a fine-cut profile and clear young coloring. $\mathrm{He}$ had been ill and had chosen to come here with his longtime friend to recuperate. It was always a mooted question whether Mr. Rogers took care of Mr. Clemens or Mr. Clemens of Mr. Rogers. It was a question that they took much delight in unsettling.

But there was no Margaret. I had been instructed to try to fill her place with some other choice soul, and that was the way the Angel Fish came into our circle. She, however, belongs to another chapter.

Mr. Clemens and Mr. Rogers secured a 
table near ours in the dining-room, and there was much visiting back and forth. The first morning, after breakfast, we met with $\mathrm{Mr}$. Rogers to organize what we were pleased to call the S. L. C. Life-Saving Society. Mr. Rogers gravely stated that Mr. Clemens, being of a guileless and unsuspecting nature, was sometimes led away by designing and not altogether desirable strangers. His kind heart could never permit him to refuse himself to anyone who might address himself to him, and the result was that he was sometimes drawn into annoying relationships. The plan of action of the S.L.C. Life-Saving Society was to be as follows: when we should see Mr. Clemens engaged in conversation with a doubtful party, we were to go up to him and say, "Pardon me, but Mr. Rogers is looking for you, and would like to speak to you immediately." Mr. Clemens, to whom was to be revealed the full significance of this phrase, would thereupon take warning and discreetly withdraw.

It was soon after their arrival that we began to call Mr. Clemens the King. The 


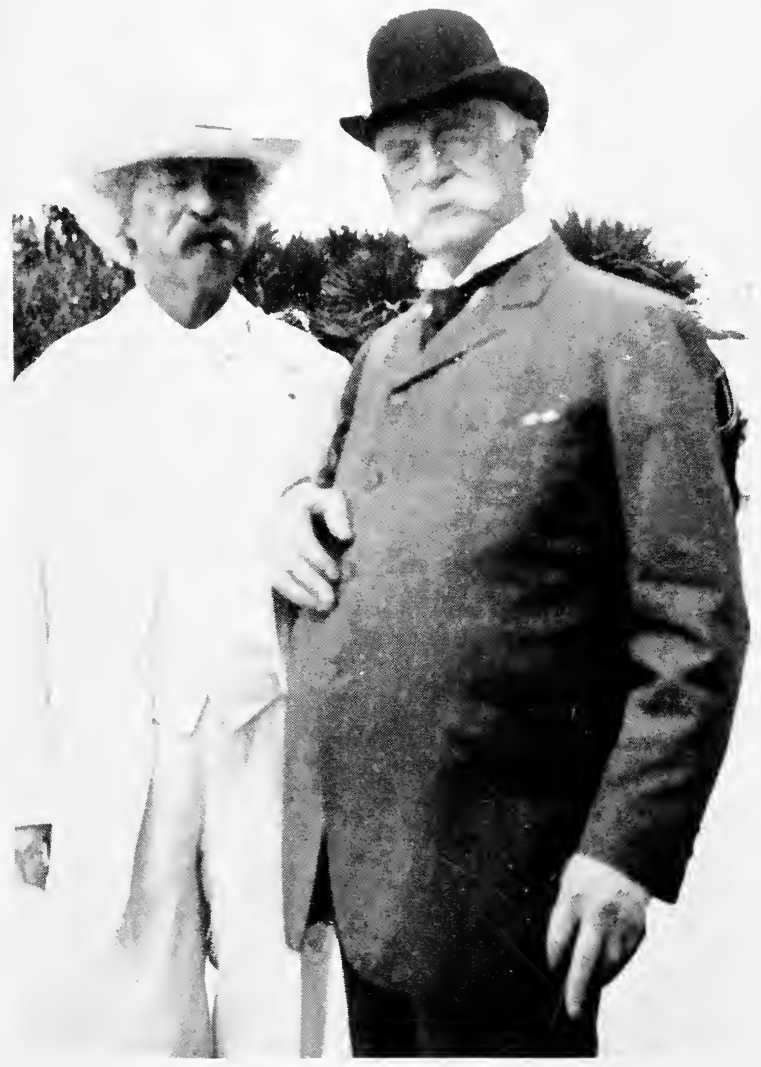

II is companion acas IIenry II. Rogers 

title had already been given to him by a small circle of loving friends. We quickly felt the appropriateness of the name, for we realized that we had never known anyone who made his personality to be felt more than he did, and yet without any effort. He just was.

The King hit upon the happy idea of calling Mr. Rogers the Rajah. And so they remained for us to the end of the chapter an ending that came, alas! all too soon.

Mr. Clemens never grew tired of poking fun at Mr. Rogers and his stately, dignified manner. One day, as the latter came into the dining-room, a little late, with his slow step, Mr. Clemens, who was already seated at the table, said, "There he comes, looking just like Gibbs' Lighthouse, stiff and tall, turning his lights from side to side!"

Their deep and strong affection for each other usually manifested itself verbally in this sort of whimsical abuse.

One of our first excursions together, after the return, was to Prospect Park.

Prospect Park has many charms, the greatest of which is the prevalence of scarlet 
military coats. For Prospect Park is the garrison, and not to go to at least one function is to be hopelessly civilian, which is another name for plebeian. None of us wished to be that. Besides, Mr. Clemens had a particularly tender spot in his heart for all things English, since the loving reception he had had the summer before from all classes on the British Isles. As we look back we see Prospect Park colored with many joys, and we were grateful to the Home Government who saw fit to retain one regiment there. To be sure, the one regiment was sorely in need of padding; but what were numbers, when among the officers were the witty Major B, the handsome, dashing A. D. C., the kindly Colonel, and the appealing, child-like subalterns?

To Prospect Park, then, we went of a Sunday, to hear the band. The truly pious went to the church services, and watched the red-coated soldiers come in and take their places in the uncomfortable little chairs, ranged in serried ranks in the barracks' church. This was a long, narrow house, built 
of wood and covered with corrugated iron, which gave it a peculiarly unchurchly aspect, and seemed to hint at a necessity for fireproof arrangements. But the Chaplain was a kindly man who refrained from speaking of the wrath to come, and confined himself to brave, encouraging words to these lads, so far from home.

We arrived a little early for the band concert and entirely too late for the services. But we drove up to the church to watch the soldiers march out. We heard the last responses in strong, virile tones, then a hymn, then a rustling of feet; and then the scarlet audience streamed out from both doors of the furnace-like building. Mr. Clemens murmured something about "flames of fire and the wrath to come." However, the bright colors soon melted away and scattered, to reassemble on the greensward of the park. Presently the band gathered under a clump of cedars, and the lovely strains sounded sweeter because, while listening, we could at the same time see the wonderful color of the sky and feel the balmy air upon our cheeks. 
The only discomfort in being with $\mathrm{Mr}$. Clemens and Mr. Rogers in a public place was that glances and cameras were always turned upon them. But they accepted this attention with indifference, and why should we be bothered? Mr. Clemens was not a passionate lover of music, but he was fond of a band or of an organ. On this particular day he was distracted from a fair attention to the program by the awkward antics of a lank puppy and a fat baby. The fat baby was evidently the direct lineal descendant of the bass-drummer, for the child lunged from time to time in his direction, laying violent but unsteady hold on the paternal legs. Indeed, all those straight, firm legs of the standing band had a wonderful attraction for the Fat Baby, and when the puppy's charms palled she would stand by her unhappy father a while, looking contemplatively at the forest of legs before her; then she would reel, and totter, and disappear among the avenues of legs, to be hauled out ignominiously when the number was over. All this Mr. Clemens ob- 


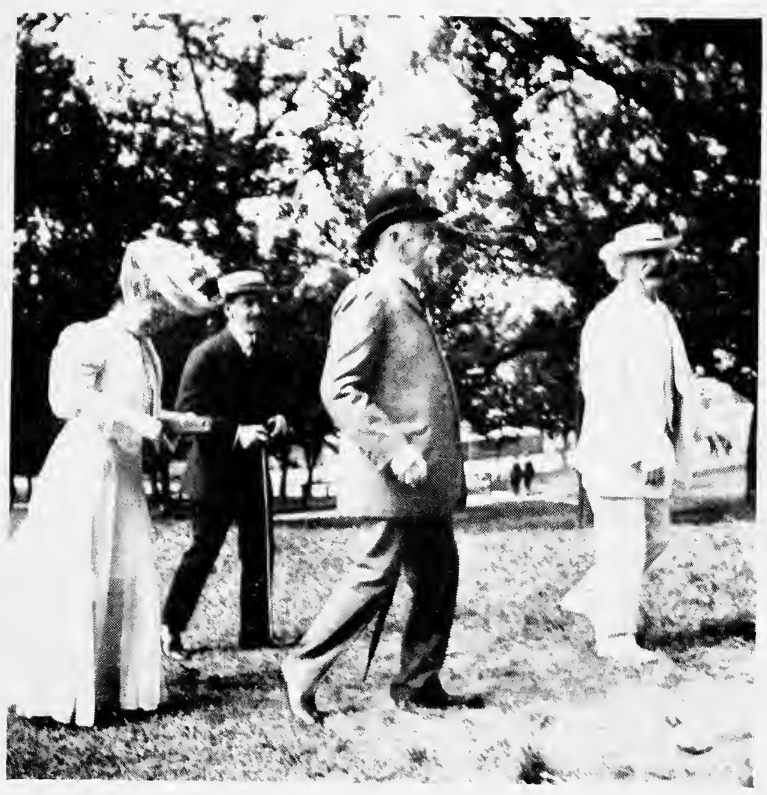

Glances and cameras were alicays trimed upon them 

served with quiet delight, making an approriate observation from time to time.

The puppy failed to interest him so much, for he had no love for dogs, and sometimes said that he wished he could exterminate them all.

Mr. Clemens directed our attention to some other children who were playing, and remarked: "They look like intoxicated Junebugs careening over the lawn."

'Two small boys strutted past, looking very important and pompous and British. We heard one say to the other: "How long are you going to stay? My mother told me I could stay until 'God saves the King." "

We, too, decided to stay until that interesting moment, and when it came we rose, a little stiffly, from the rug on which we had been reposing, and joined in the national anthem with fraternal regard. As Mr. Clemens bared his white head, he looked, indeed, a kingly figure clothed in white against the scarlet background of the band. 

2Battlesbips and Society 



\section{CHAPTER VII}

\section{BATTLESHIPS AND SOCIETY}

NE day three English cruisers came into the harbor. The next evening Mr. Clemens received a charming letter from the Chaplain of one of them, a letter which pleased him much because of its quaint phrasing. Here it is, in part:

Dear Doctor Clemens: I understand we are cousins and in a closer sense than that you are American and I English. Your dear mother is sister to my (to me) dearer mother!

I am jealous that my Alma Mater was forestalled by Oxford in adopting you.

I regret, also, that the exigencies of the service prevented my being in Oxford - in fact, England - to assist those who desired to do you honor. Think you that we might square yards in some way? May I suggest a way? What if you did us the honour to lunch on board the battleship on Monday or Tuesday? Does that appeal to your sense of humour? If not, will you let it touch that whole-hearted generosity of yours, and come? 
We won't ask you to say anything funny, but will, if you will honour us, show you as much of the ship as you might wish to see, and do our best not to bore you too much.

I have a confession to make - my conscience compels me. Here it is - Fleet-Surgeon Fand I made a pilgrimage yesterday to your present shrine to do you homage. We had one golden opportunity, when you were smoking your after breakfast eigar on the terrace of the hotel, but being the shyest of a shy race, or let me say, the kindest of our kind, we refrained from taking advantage of your only moment of isolation to attack you and achieve the object of our visit.

The letter went on to name days and hours when Mr. Clemens might favor them, and wound up with:

I must apologize for the length of this invitation. My excuse is, that it is not so much an invitation as a humble petition from two

Grateful Admirers-in-Chief.

Of course Mr. Clemens went, and had a beautiful time, and made a speech that made them rock with laughter and then furtively wipe away tears. The Chaplain told us about it afterwards. That is the way we knew. And Mr. Clemens also told the Chaplain about his 


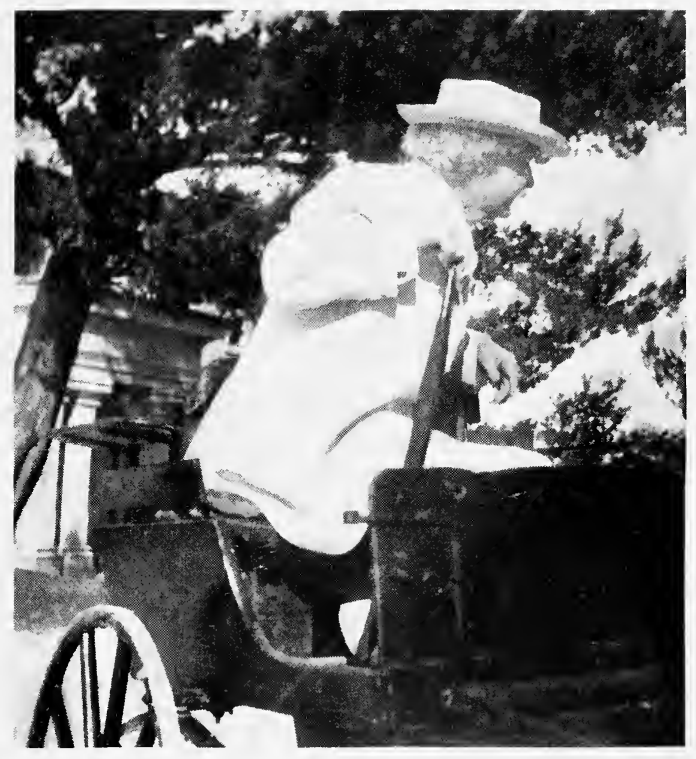

The Chaplain's cousin 

friends, so that a boat was sent for us and we had afternoon tea on board. The Chaplain had a hospitable soul, as well as a graceful pen and the happy gift of speech, so that he made a royal good host. We saw the six hundred men of the battleship stand up in straight military lines on the forward deck and answer to roll-call. Then the shore-leave men scrambled down into their boats, held up their oars in perfect vertical lines, dropped them at the word of command, and rowed off cheerily, to have a respectable British orgy in the staid town of the island.

Then we, in our turn, scrambled down to our boat, the crew gave a cheer for $\mathrm{Mr}$. Clemens, and as the launch moved away we waved lingering farewells to the old grey cruiser.

Almost all social functions, and there were many on the little island, Mr. Clemens escaped. Once in a while he was persuaded to go to an afternoon tea. These were very popular. On these occasions innumerable kinds of rich cake were served, in such reckless profusion and with such pressing hospitality that dinner was 
completely wrecked. But when we were all invited to a West-Indian Pepper-Pot luncheon, we eagerly accepted. Our hostess was not a born islander, but as fourteen or fifteen winters had sheltered her on the Happy Isles, she was an adopted daughter. Besides, she knew how Pepper-Pot was made, and this, added to other charms, made her quite irresistible. She laughingly told us that Pepper-Pot was best on Sunday, for it was a heathen dish. Its origin was clothed in mystery.

It takes three or four days to cook PepperPot, but when it is done it is a worthy creation. Dark, rich, heterogeneous, with an unanalysable flavor, it possesses an apparently mild flavor until you have half finished your dishful. Then it begins to burn insidiously, first your tongue, then your palate, then your throat, until you feel gently aflame. It is not a wholly unpleasant sensation, and we all ate bravely.

Mr. Clemens remarked, when the silence of discovery had first fallen upon us, "This would be a very good dish if it had a little 
pepper in it." We all smiled humidly, and furtively wiped our eyes.

After luncheon some curious neighbors came in to call, and among them was one who did not win the affection of any of us, nor of Mr. Clemens, whom she particularly wished to impress. We had an opportunity then of seeing Mr. Clemens's tactics. He had a wonderful way of suddenly disappearing, of slipping into space, of melting into a misty background, when he wished to escape a person who bored him, that was the perfection of art. Sometimes, when circumstances prevented this disappearance of his physical self, he nevertheless absented himself mentally, so that the undesired one felt, all at once, that he was talking to the unanswering air. Withal Mr. Clemens always remained courteous and dignified, and never for an instant conveyed the thought of rudeness. Indeed, we never saw him angry or impatient except when he could not find a match-box in his pocket, or when his waitress failed to bring him his bacon grilled as he liked it. Even then he was simply 
whimsical in his wrath. The great disturbances usually found him calm and philosophical.

Mr. Clemens cared nothing for the excursions, that were sometimes proposed, to visit some object of interest. He used to say that he had probably seen the oldest house in the world, the longest street, the biggest city, the most wonderful cathedral, the highest mountain - so why should he bother himself now, in his old age, to see second-rate curiosities? So he showed no interest in crystal caves, nor natural bridges, nor coral gardens, but he loved to sit on the veranda and drink in the changing beauty of sky and sea, or to take long drives under cedar arches or over palmshaded roads that ended suddenly in the surf.

He never played golf, that we knew of, but he was exceedingly fond of billiards. It was a pretty sight to see him teaching his little girl friends to play, and encouraging them by letting them beat him.

In the evening we often used to play cards in his room. The only game we ever played was Hearts. Mr. Clemens usually prefaced the game by saying to Mr. Rogers, in a tone 


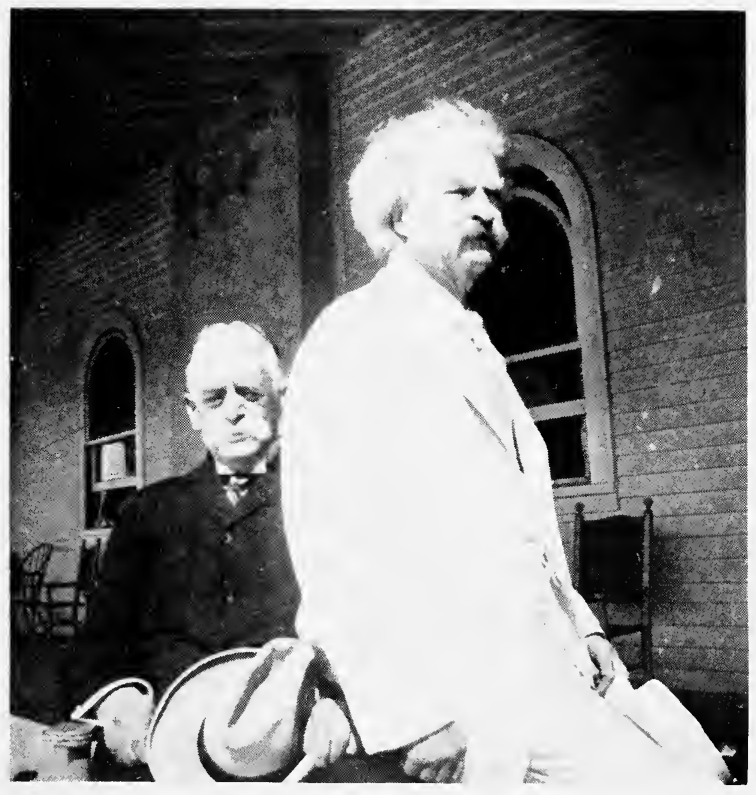

They assumed a high moral attitude 
E 
of kindly remonstrance: "Now, I sincerely hope you are not going to make any display of your disagreeable disposition tonight. Do try to show us some pleasant sides of your character."

Mr. Rogers, with a perfectly serious face, replied in the same vein, and this was kept up throughout the evening, so skillfully that the other two never grew weary. On the contrary, we were convulsed with silent mirth.

They, Mr. Clemens and Mr. Rogers, each had a theory that the other would be a hopeless outcast were it not for his regenerating influence. They assumed a high moral and didactic manner when they reasoned with one another.

Sometimes, however, there was a sweet gravity in their intercourse, and that was at such moments as when Mr. Clemens read McAndrews' prayer and Mr. Rogers listened, with a moisture in his eyes, to the beautiful pathos of his friend's voice. 

Đ9atk $\mathbb{C} \mathfrak{m a i n}$ 's aquarium 



\section{CHAP'TER VIII}

\section{MARK TWAIN'S AQUARIUM}

$\mathrm{N}$ one of the three hundred and sixtyfive islets that group about the Happy Isle was an aquarium. As it used to be a store-house for powder and other food for guns and cannon, it was all the more picturesque as a house for fish.

Mr. Clemens beguiled into going there one day by the genial and obliging Consul, took Mr. Rogers and the rest of us with him. It was a beautiful Sunday morning, and the sun brought out all sorts of unexpected lights on the water. The fish in the aquarium were very wonderful in their coloring and form, but Mr. Clemens did n't seem to think that they were very sociable. And it was n't pleasant to see the octopus dine off a retiring and harmless crab, nor to see the keeper stuffing live eels down the lazy moreau's throat.

There were four-eyed fish and squirrel-fish and parrot-fish, and I don't know how many 
other kinds of streaked and barred and polkadotted curiosities. But the kind that $\mathrm{Mr}$. Clemens picked out as his favorite was the Angel-fish. They were plump, and had fins like wings, and were gorgeous in their coloring and had pretty little pursed-up mouths that suggested maidenly modesty. Their wings suggested spirituality, and their coloring femininity. These traits appealed especially to Mr. Clemens, and, not long after, Mr. Clemens's aquarium was established. In this aquarium there were to be none but Angel-fish admitted. To be an Angel-fish one must be a girl, and one must be young, and one must have won Mr. Clemens's heart. This latter was not hard to do, for he always made the overtures when he first met, or saw, any promising candidate. Margaret was, I think, morally speaking, the first real Angel-fish, but Irene was the first one to be so-called. She was Margaret's direct successor in the donkeycart, and many a lovely morning she and Mr. Clemens and Maude ambled off to Spanish Point, while the faithful followed or preceded, according to Maude's gait. 


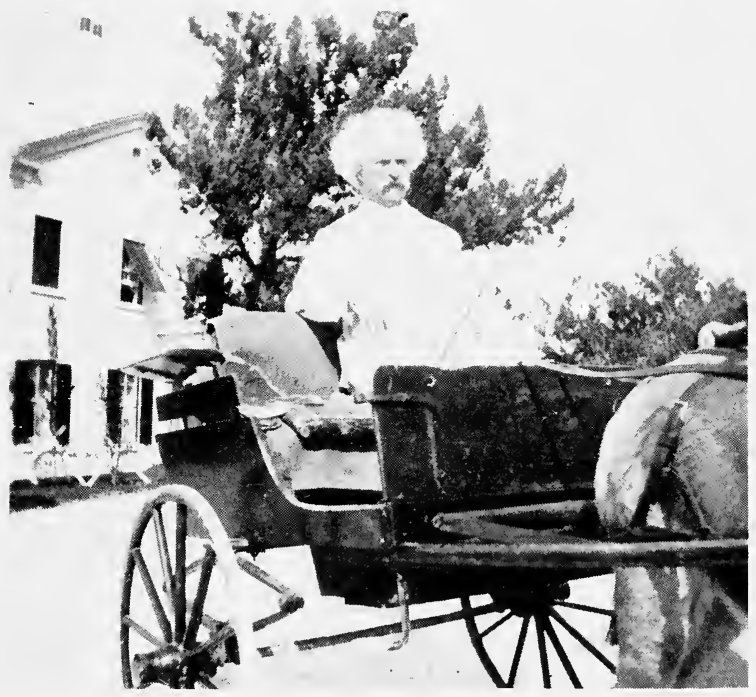

IIis light weight conld not discourage her 


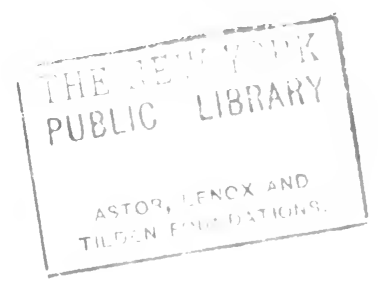


One morning, when we were returning after a happy jaunt, Mr. Rogers began to berate Mr. Clemens for riding longer than was his turn. Mr. Clemens defended himself by saying that it was purely out of consideration for Maude, as his light weight could not discourage her, whereas Mr. Rogers's heavy form would be a burden too great for her. The result of the discussion was that $\mathbf{M r}$. Rogers and I got into the cart, while Mr. Clemens, the Angel-fish, and the others walked behind. Despite our efforts, Maude could not be made to see the advantage of going rapidly, and when we came to the hill in front of the hotel she stopped completely and went down on her knees - her final argument. I tender-heartedly suggested getting out and helping Maude up the incline. But Mr. Rogers had a happier plan, which was to make Mr. Clemens push the cart up the hill. Mr. Clemens demurred at first, but submitted with good grace, and Maude, encouraged by the sympathetic friend in the rear, pricked up her long, sad ears, and we dashed up to the 
front entrance in fine style, with the Angelfish following fast behind.

Others were later made members of the King's aquarium, and to each one was given a pretty enameled pin in the shape of an Angel-fish, which she was to wear as often as possible.

When Mr. Clemens could not have one of his Angel-fish with him, then the next best thing was to talk about them.

One evening he told us of far-away Dorothy. He had said to her one time: "Dear- [to hear Mr. Clemens say "dear" to one of his little girl friends was a revelation of the wealth of affection in that one syllable] - I love you so that I think I really will have to eat you up!" And Dorothy responded, quick as a flash: "Oh, don't! Mr. Clemens; you would miss me so!" How Mr. Clemens chuckled over this! And he told another story of this same Dorothy. They were at breakfast and Dorothy was eating her egg. Mr. Clemens began by saying: "Is n't this egg a wonderful thing, so curiously made, so marvelously constructed! I wonder how it all came 


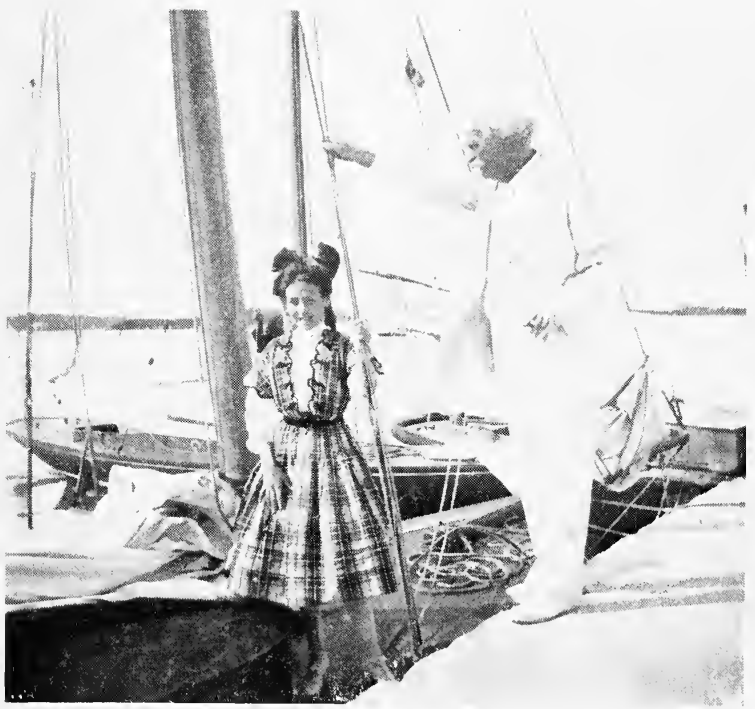

T'lee Angel-fish came into our arele 

about!" And Dorothy responded, practically: "Why, they're just made to keep the hens busy."

There were two or three Dorothys among the Angel-fish, and it was hard for Mr. Clemens to tell which he loved best.

One of Mr. Clemens's household wrote me later an incident of one of the other Dorothys which had filled Mr. Clemens's soul with joy. This Dorothy was at his house in New York one day. She was twelve years old and shone as an authoress. Sitting by the King's side, she wrote a story, handing him each sheet as it was finished. It was something as follows: "A man was seated in a chair by the fireside, brooding over his troubles. He was sad because his wife was dead. Suddenly a spectre appeared before him, and it was his wife. She said: 'Dear, I could not bear to see you so sad and discontented, so I have come to comfort you. You must not be sad. You must be bright and happy. It was best that I should leave you when I did, because I was going to get a divorce.' Then she disappeared. The man 
sat for a while longer, and then said to himself : "Yes, it is best to be contented."' Dorothy asked for the last sheet again after she had handed it to the King, saying she did not quite like the ending. The King gravely returned it to her, and she added "with what is ordained," and reread the sentence with satisfaction: "Yes, it is best to be contented with what is ordained."

This was the kind of society that Mr. Clemens loved best those last days of his life.

There was a boyishness about Mr. Clemens sometimes that found different modes of expression. Once, when the long corridor of the second floor of the hotel presented a temptingly empty avenue, he hopped, skipped, and ran, and then gave a delicious suggestion of a cake-walk. As soon as a door opened, however, he stopped and assumed a supernaturally grave aspect.

Another time - it was of a Sunday evening - I heard a mysteriously gentle knock at my door, and, opening it, saw Mr. Clemens. He put his finger to his lips and said "Hush!" For the Lady Mother's room adjoined. Then, 


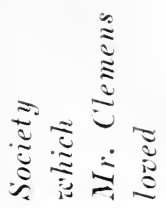

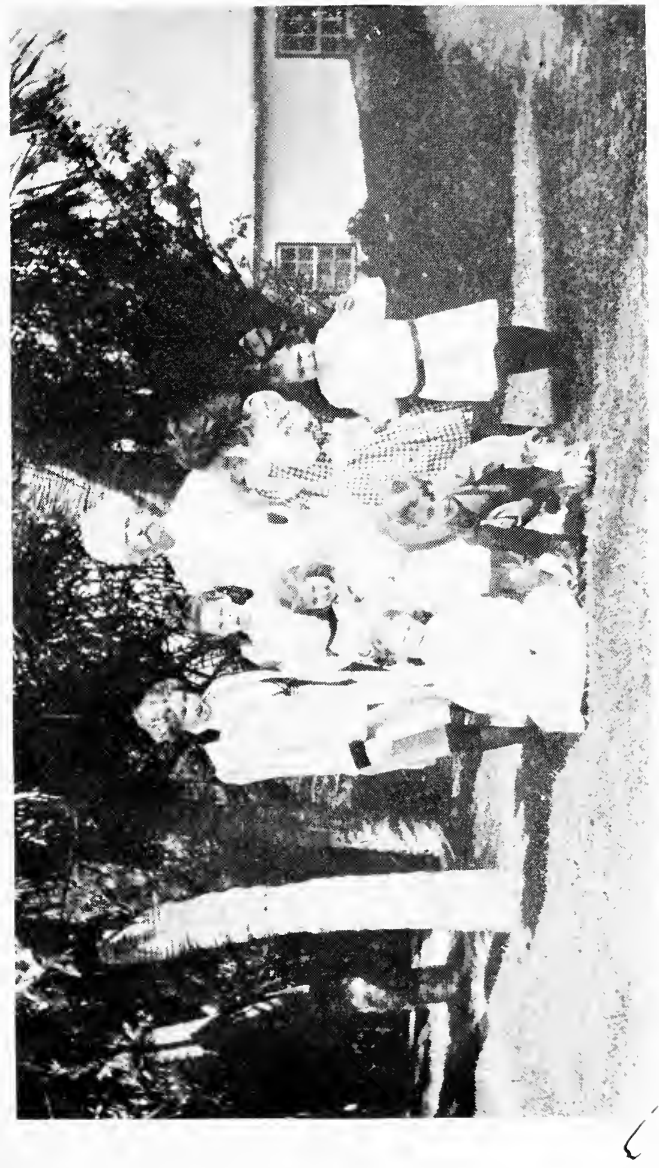



beckoning me out into the hall, he whispered, "Can't you run away and have a game of cards?" To my reply of "I'm afraid mother won't let me; it's Sunday evening," he rejoined, "Play hookey; she'll never know." So, closing the door, we escaped down the hall, with a well-simulated thrill of adventure, while the dear Lady Mother remained sweetly unconscious of the perfidy. 

Dods and $\mathbb{E n O s}$ 



\section{CHAPTER IX}

\section{ODDS AND ENDS}

$\mathbf{M}^{1}$

R. CLEMENS was delighted when one day he found an English edition of his book, A Stolen White Elephant, and Other Stories. It was bound in brilliant scarlet, with the picture of a white elephant on the cover. Some of the sketches contained in this volume he had not seen for years. The chapter entitled Notes of an Idle Excursion was particularly to the point, for the excursion described was to this same Happy Island, and had been written thirty or more years before. He read it aloud to us one evening, and we marveled at the freshness of description. Either the island had remained the same or the magic power of the writer made it ageless. Mr. Clemens had a quaint way of pronouncing the island's name that seemed to hark back to the days of Shakespeare and "vexed Bermoothes isle." He always said "Bermooda," and the name seemed to fit. 
In this same collection of stories is recounted the incident illustrating the base ingratitude of the young aspirant to literary fame, who is helped by an author and who later on attacks his benefactor. The story points the agreeable moral that it doesn't pay to render that sort of help. If this was a theory of Mr. Clemens, it certainly was not his practice. One day at the hotel Mr. Clemens discovered that a would-be author earnestly desired to have his opinion of a manuscript, but was too timid to ask him to read it. He forthwith asked the author to read him some of his work. We were on the veranda, and we watched Mr. Clemens as he listened. The reading interested him and he sat with his head bent, leaning forward in his chair, his eyes hidden by the bushy eyebrows. How deeply interested, we could not tell, and we waited rather breathlessly when the anxious author's voice ceased. The King looked up and there was moisture in his eyes. He said slowly: "I was just wondering what publisher would be worthy of publishing such a beautiful piece of work." The startled joy 


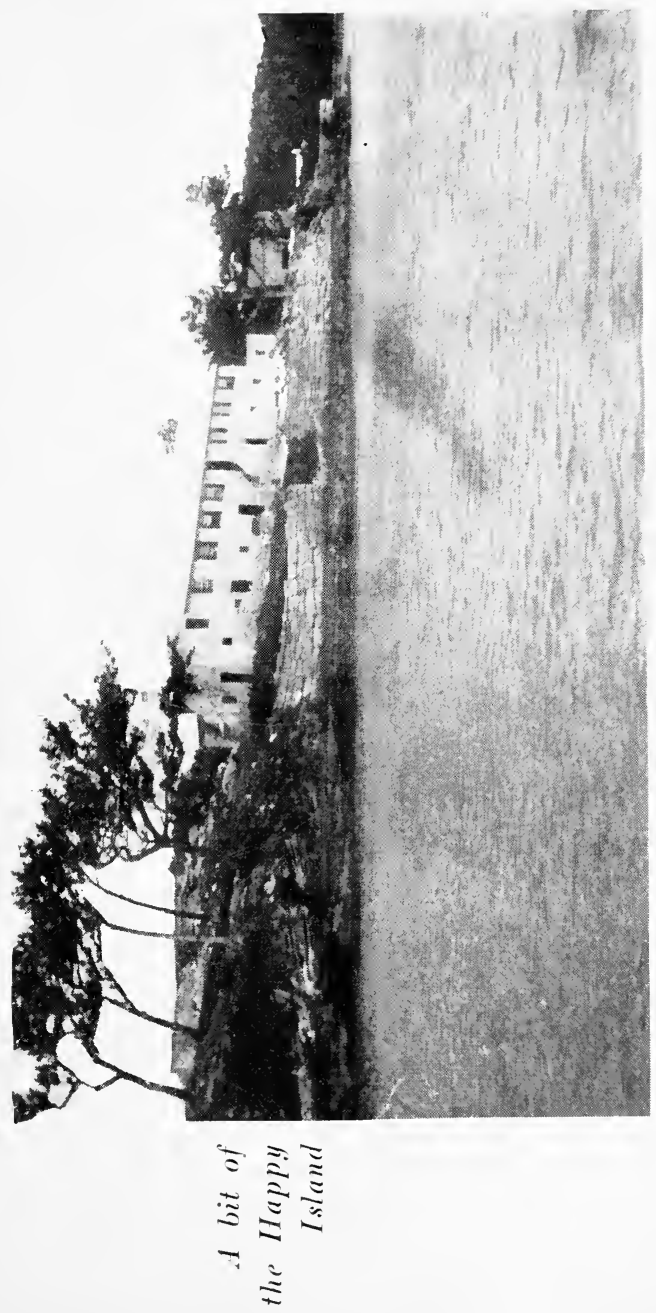




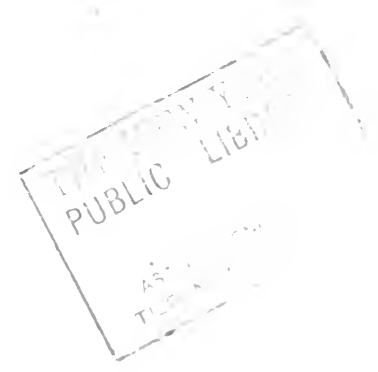


on the author's face was almost funny. We happened to know that Mr. Clemens's interest did not end there, and that he made certain practical suggestions which were most helpful.

Mr. Clemens's generous spirit was shown in another way when the Children's Hospital Benefit was given. The management asked him if he would occupy the principal place on the program and make a speech, or tell stories, or, in fact, do anything he pleased. Mr. Clemens readily consented. He was the drawing-card, of course, and when the evening came the hotel parlors were packed to suffocation.

There is no need to describe Mr. Clemens as a public speaker, but on this evening something happened which, Mr. Rogers said, had never, to his knowledge, occurred before. Mr. Clemens was telling his well-known story of the first time he met General Miles in Washington, and of his successful and successive efforts to sell the dog. Everyone who has heard Mr. Clemens tell his stories will remember that he never, never laughed while relating them, no matter how excruciatingly absurd 
the story was. His unbroken gravity always added immensely to the effect on his audience. This time, however, when he reached the climax of the story, he suddenly broke down and laughed, laughed so hard that for a minute he could not go on. And the audience shook with mirth because of the unexpectedness of it.

One day we decided to have an all-day picnic and drive out to the far end of the island and take lunch in a quaint inn whose glories we had heard sung. Our party filled three or four carriages, and we had a long and very merry ride. But alas for our expectations! When we arrived we found the oncepicturesque hostelry newly refurnished. The proprietor had evidently inherited some of the worst tendencies of the early Victorian period of interior decoration, and the rooms were a riot of color, varnish, and silk tidies. After we had been greeted, and our orders had been given, and we were trying to assimilate the local coloring of the parlor, Mr. Clemens gravely and sadly remarked: "It looks more like a wrecked kaleidoscope than anything I've seen for a long time!" This faculty of 


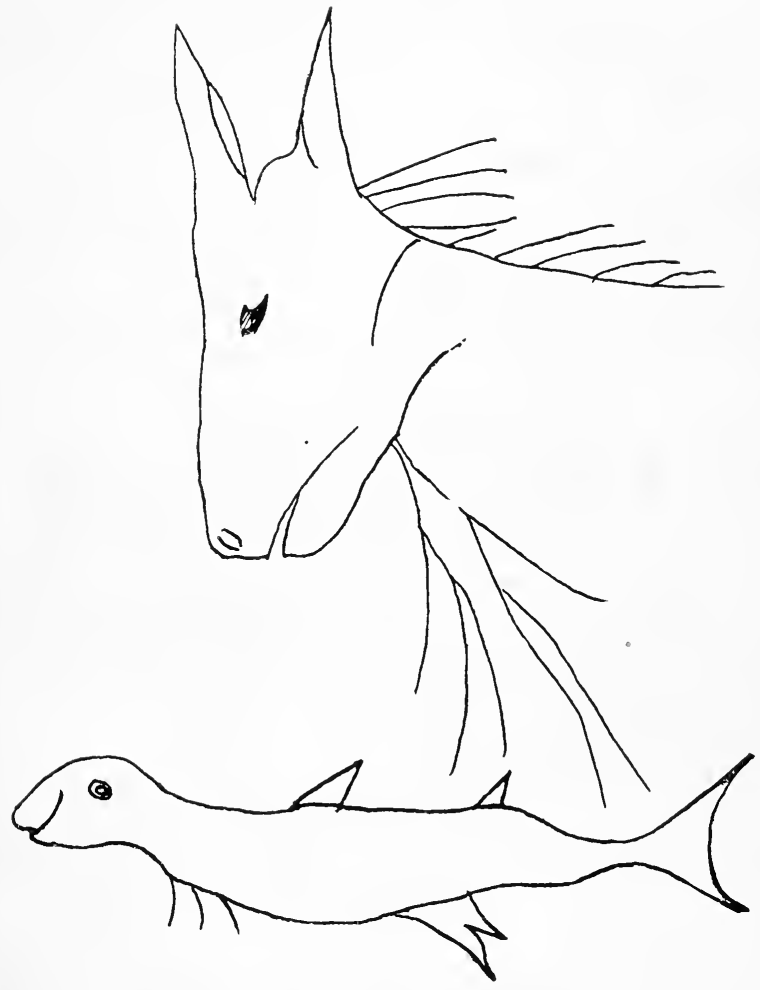

Maude's expression weas hard to catch 
$\therefore$

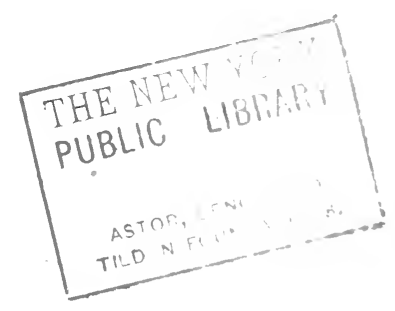


Mr. Clemens for finding unexpected but perfectly fitting similes and adjectives was a never-ending joy to the rest of us.

Mr. Clemens had no great talent for drawing, and though he could make word pictures, his pencil pictures were difficult to recognize. One afternoon he suggested that we embroider some tapestry, for which he would make the designs. For my pattern he chose as the central figure the head of Maude. Beneath was to be a fish, also emblematic of the island, and in the upper left-hand corner was to be worked the legend, "Ste. Maude." With a blue pencil he tried to make a donkey's head. The first attempt looked too much like a cat, the second like a cow, but finally the third satisfied him. The fish was easier to make, because less intelligent-looking, Mr. Clemens said. It was Maude's expression that was so hard to catch.

The design was transferred by him to the canvas and was outlined in properly colored silks. But it lies unfinished, a mute reminder of the happy afternoon when we laughed like children over the series of tapestried figures 
we were going to make to hand down to posterity.

One evening Mr. Clemens was led to talk of his life on the Mississippi. His cigars were good, and we were sitting in a quiet corner of the big reading-room, and he had an appreciative audience, so that he fell into a sort of inspired monologue. I remember, but cannot transcribe, alas! the marvelous descriptions he gave of the mighty river. $\mathrm{He}$ seemed to be carried back to his youthful days and to see again the rushing current, the changing shores, the glowing sunsets. The descriptions of this evening seemed to me more vivid, more evoking, than the written ones of $O n$ the Mississippi. And they are masterpieces. But the added charm lay, doubtless, in the picturesqueness of the narrator, who sat as in a vision, his white head and strong features enveloped in a cloud of smoke, out of which his voice came to us vibrating with reminiscent feeling. 
Cbe king and Kkipling 



\section{CHAPTER $\mathrm{X}$}

\section{THE KING AND KIPLING}

$\mathrm{E}$

VENINGS at a hotel, even a hotel on the Happy Island, are, at best, garish. There are verandas, where a swaying multitude rock back and forth in huge wicker rocking-chairs; parlors, where old ladies play bridge; and smoking-rooms, where the men, pleasantly wearied from golf, somnolently pull at their cigars; and a ball-room, where expectant young girls listen to the music of a discouraged band.

But our evenings were different, for we fled from all these allurements, and gathered in Mr. Clemens's room, where we spent most delectable hours.

Mr. Clemens had a wonderful gift for reading. The author of The Prince and the Pauper, Huckleberry Finn, and Tom Sawyer could not fail to be dramatic. And this dramatic sense he knew well how to express in 
his reading. He read slowly, with eloquent pauses, and he threw himself into the sentiment he was interpreting with intense abandonment, and yet with a reserve that was consummate art. One evening he read to us some articles by Helen Keller, that were then appearing in Harper's Magazine. Every now and then he would interrupt himself to comment on some phase of Miss Keller's personality, or recount some incident of his acquaintance with her. Mr. Rogers, too, knew her well, and they both agreed that Miss Keller had proved it was quite unnecessary for us to have so many senses. Another evening he read to us from his own unpublished manuscript - stories of his little girl friends, charming sketches of Dorothy and Margaret and Irene, of his first meetings with them, and of their quaint sayings.

But $I$ think that the evenings we enjoyed most were those when he read Kipling. He said once: "I'm not fond of all poetry, but there's something in Kipling that appeals to me. I guess he 's just about my level."

He loved the swing of Kipling's verse and 


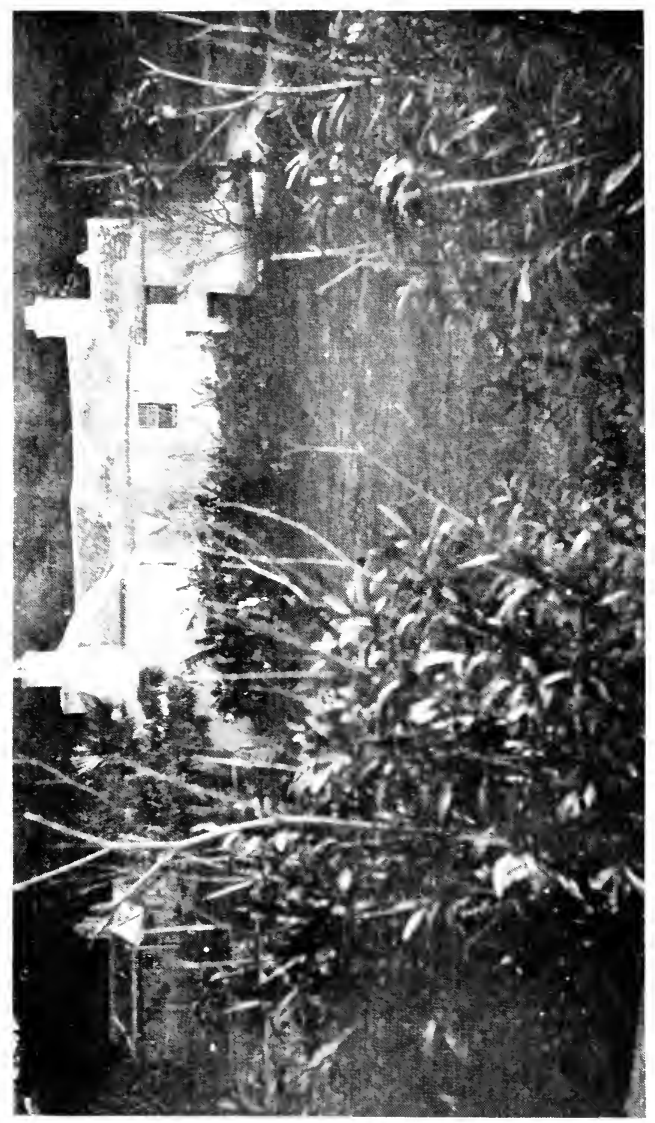

$$
\begin{aligned}
& \begin{array}{l}
\vdots \vdots \\
\vdots \\
\vdots \\
\vdots \\
\vdots \\
\vdots \\
\vdots
\end{array} \\
& \text { 过 }
\end{aligned}
$$



the brawn and muscle of his thought. On those Kipling evenings, the mise-en-scène was a striking one. There was the bare hotel room, with its pine woodwork and pine furniture, and the loose windows, which rattled in the sea wind. Once in a while a gust of asthmatic music from the spiritless orchestra, down stairs, puffed up the hallway. Yellow, unprotected gas-lights burned uncertainly, and Mr. Clemens, in the midst of this, lay on his bed, still dressed in his white serge suit, with the light from the jet shining down on his silver hair, making it gleam and glisten like frost.

In one hand he held his book; in the other he had his pipe, which he used principally to gesticulate with in the most dramatic passages.

Then we sat down near him, and Mr. Rogers lit his cigar, remarking kindly: "Now, Mr. Clemens, don't read too slowly. It seems to me that sometimes you drawl a little," to which Mr. Clemens replied, looking genially up at the ceiling: "It's most unfortunate that Mr. Rogers speaks so indistinctly. I often lose what he says, entirely." 
And then Mr. Clemens began. When he read the Mary Gloster we could see the violent old man lying on his death-bed, undaunted by the thought of the end, pouring bitter curses on his worthless son's head, and at the same time thrilling with his sublimely poetic purpose. The tender beauty of Mr. Clemens's voice when the old man spoke of his one dear love, made the feminine members of the audience weep openly, while Mr. Rogers sat up sternly, blinked hard, and pulled fiercely at his cigar. When Mr. Clemens read McAndrews' Hymn his voice rang out in triumph and his pipe waved rhythmically to the song of the steam. Soldier and Sailor Too swept us out to visions of the sea, and of men who died at their posts; while we laughed delightedly with the swing of The Bolivar, and felt the note of piercing homesickness in Mandalay and $M e$ That Has Been What I've Been.

One evening the Lady Mother was able to be present, and Mr. Clemens chose Tomlinson for her delectation.

It was an impressive sight-those two types, each so beautiful in ways so utterly different: 
Mr. Clemens, who had seen the world in all its phases, of sin and pleasure, of joy and sorrow, and who had come out of it with a nature still sweet, a philosophy half-whimsical, halfprofound, and a heart where youthful gaiety still had a place; and opposite him the Lady Mother, with her pose of a duchess, the young look in her eyes, and her finely chiseled face, flushed with a happy look of expectancy. Both had lived the same number of years, she so protected from, he so exposed to, their storms. And he chose Tomlinson. I shall not say that she enjoyed it. Some of the expressions had not that refinement that she loved, but if she did not wholly approve Kipling, she gave full meed of praise to the King. Him she never criticized.

Mr. Clemens gave to several of his friends who had at different times enjoyed Kipling with him a copy of the writer's collected verses, marking his favorite poems with heavy lines.

From one friend to whom he sent such a copy came back, in acknowledgment, the following verses: 


\section{When the King Reads Kipling}

I

When the King reads Kipling

We grow silent and are still,

And our hearts begin to thrill,

For we know we shall be carried to far lands across the seas.

We shall tramp through tropic forests, we shall rest 'neath banyan trees,

Where we hear the lazy $r i$ stling of palmettos in the breeze.

We shall feel like happy children, for we haven't any choice

When we hear the East a-calling with its yearning languorous voice,

When the King reads Kipling.

\section{II}

When the King reads Kipling,

We are spell-bound, by the ring

Of the ballads, as they sing

Of the ocean's awful power and its deep deceitful wiles:

Of the desert's naked grandeur, where the green oasis smiles:

Of the splendor of horizons glowing blood-red, miles on miles:

And our souls are stirred within us and we feel a glad unrest

For we are sailing outward, to the Islands of the Blest

When the King reads Kipling. 


\section{The King and Kipling}

\section{III}

When the King reads Kipling,

There's a hush falls on the room

In the twilight's deepening gloom.

And our hearts are strangely lifted to some distant purple height,

Where we catch a glorious vision of the soul's heroic might;

Where we hear the cries of anguish, that come sobbing through the night.

And we feel the tragic shadow, that makes great joys complete,

For we are borne up to the mountains where two great poets meet,

When the King reads Kipling.

Mr. Clemens was deeply touched and wrote the following answer:

You have overwhelmed me, dear —. That poem does not seem like words - a march of words with interrupting spaces between - it flows like organ music, in blended strains, deep and rich and eloquent. And so moving! I can't read it aloud, my voice breaks. It is noble, stately, beautiful! I can never thank you with words, but I can with my heart; and I do.

Affectionately,

S. I. C. 
But time passes on a Happy Island as it does everywhere else, and the inevitable day came when we had to sail away, and wave a lingering good-bye to the kingly white figure on the shore, and sadly watch the green islands sink into the sea.

We wondered if we should ever see him again, but we were certain that, whether we ever did or not, his image could never fade from our hearts. We should always hear that dear, drawling, resonant voice. We should forever keep in our memory that marvelous personality. 
Stormfícld 



\section{CHAP'TER XI}

\section{STORMFIELD}

KING, whether he be one by the acciA dental right of inheritance or by the noble right of inborn royalty, has the privilege of calling his vassals to him at his will. So when a summons came, the Thanksgiving following the winter on the Happy Island, for me to go to Mr. Clemens's home in the Connecticut hills, I never thought of hesitating.

It was Thanksgiving afternoon when I reached the little station. It was a glorious sunny winter day, with a gray frost still on the hills, little icicles on the edge of the streams, and a tang in the air that gave to hearts and cheeks a cheerier glow.

We drove rapidly over the country roads, and I noticed at each turning that there was a neat and very diminutive sign-board, pointing always in the direction we followed, and bearing the initials $\mathrm{M}$. $\mathrm{T}$. 
Many minutes before we reached it we could see the peaceful white Italian villa, from whose many windows we knew we could look for miles over the country. The grounds were unspoiled by the hand of the landscapegardener, and bushes grew everywhere, while the graveled road, that led up to the entrance, was not yet hardened by excessive travel. We drove up to the door. It opened, and there stood Mr. Clemens. It might have been yesterday that I had seen him last, for he had not changed. His suit was as white and immaculate as ever, his hair as silvery. There was only one change. He had tied a bow of pink ribbon to the top locks of his head, in honor of the guest. $\mathrm{He}$ extended both hands in cordial greeting, and I knew then that the Happy Island had not been a dream. The bow of pink ribbon was gently referred to, with proper acknowledgment of its hospitable significance. Mr. Clemens received the thanks gravely, and then the ornament placed there whimsically was apparently forgotten, but remained coquettishly pert all the rest of the evening. 


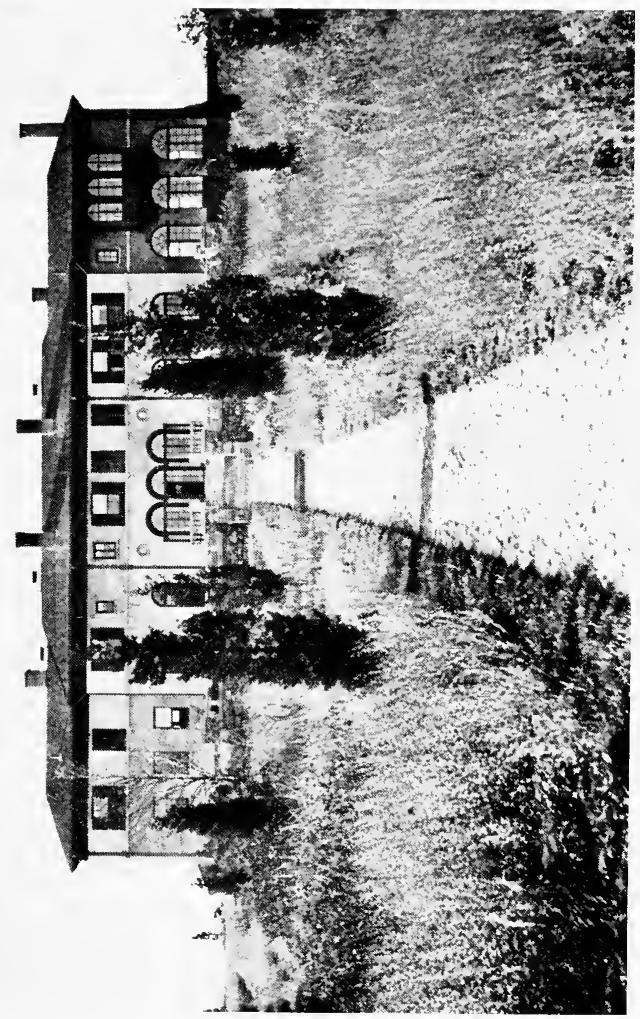

$\frac{\pi}{2}$ 
<smiles>C=CCCC</smiles> 
Even before I went to my room I must look over the house. So we went from livingroom to loggia and back again to the diningroom, and then down to the pergola, back again to the house and into the billiard-room, then upstairs to catch a glimpse of the view from Mr. Clemens' room before the twilight should close in upon it. Then Clara Clemens's charming suite of rooms must be visited, then the other bed-rooms, and the guestrooms. We must have a peep also into the servants' quarters, but finally, we stopped, before reaching the attic, which was reserved to another time.

The house was designed by the son of his life-long friend, Mr. W. D. Howells, a fact which gave Mr. Clemens great satisfaction. It was singularly in keeping with the dark, straight cedars which nature had foreseeingly disposed in decorative lines and groups. Inside there was spaciousness, light, perfect comfort, and simplicity: while outside there was all the beauty of a New England landscape at its best, with nothing abrupt or harsh in the undulating curves of its hills and val- 
leys; with something maternal in its soft, full outlines - where it would seem a sweet and restful thing to lay one's tired body down and let this mother Earth soothe and enfold you.

Mr. Clemens told me, almost with glee, that he had never seen either house or land until one day, the preceding June, when he came and took possession of a fully furnished and settled kingdom. All the instructions he had given were, that his room should be a quiet one, that the billiard-room should be big enough so that when he played he would not have to jab his cue into the wall, and that there should be a living-room at least forty by twenty feet. He was perfectly satisfied with the result, and wandered delightedly from room to room as he pointed out this and that particular charm.

As twilight fell, we gathered about the big fireplace in the living-room. Mr. Clemens asked me if I noticed anything very peculiar about the room. I vainly tried to perceive some eccentricity, but could not, for everything was in perfect harmony. "Have n't you noticed," said he, "that there is n't a picture on 
the walls?" I had to confess that I had n't. We sat and talked of our friends of the Happy Island - of the Rajah, and of Margaret and the other Angel-fish, until it was time to go and dress for dinner.

This was a function where conversation was as important as food. Mr. Clemens grew restless before many courses had been served, and rose, to walk up and down the dining-room, discoursing the while on some favorite topic. This he often did at meals. For he was not a hearty eater, except spasmodically, and so he would often suddenly rise, still talking, and continue his tirade while pacing the floor. Then, if another course tempted him, he would come back and partake of it.

There was a big organ at one end of the living-room, with a self-playing attachment, and after dinner we had some music. One of the guests played.while we sat in the firelight, and Mr. Clemens in his big armchair smoked and was perfectly happy.

Mr. Clemens spent half of each morning in bed, and sometimes he did not appear until lunch-time; but the morning after Thanks- 
giving he was downstairs at ten, and proposed that we take a walk over the hills, his hills.

It was a gloriously bright, crisp, cold day, and the atmosphere was so limpid that we could see far away. Mr. Clemens put on a fur-lined great-coat and his gray cap, saw that there was a goodly supply of cigars in his pockets, and we started off down the walk, through the pergola, and picked our way to a winding path that led us to all sorts of charming places.

Just as we were starting from the house, Mr. Clemens had stopped me and had said: "I want you to look at this view." I looked at the slope below, that dipped down into a pretty valley, and then at the gentle hills beyond, where winter had forced the trees to drop their sheltering screens, so that unexpected houses and isolated farms were here and there revealed. Mr. Clemens asked, "Do you see that white building over there?" pointing, at the same time, to what was unmistakably a country church. $\mathrm{He}$ went on: "We've just discovered that it is a church. It's the nearest one. Just at a safe distance 
All summer we thought that it was a windmill."

That morning walk in the white November sunlight will always remain a vivid memory.

We scrambled down the hillside and came to the stream, which Mr. Clemens pointed out to me with the proud gesture of a discoverer. It was just what a New England stream should be, winding and clear, flowing at times turbulently over obstructing stones, and then pausing to form a still, golden-brown pool. We followed its windings with happy delight, finding new beauties to show to each other and to exclaim over. Mr. Clemens told me Indian stories and legends he had heard in his boyhood days.

We came to a tiny cave, at the side of the road, where there were some baby stalactites, and Mr. Clemens stopped there to discourse on the wonders of geology. He told me he had lately been investigating the subject of the formation of the earth, and he had found it so wonderful that he wanted to know more about it. He had found some old treatises on geology which amused him greatly, but he 
wanted to get some more modern and scientific information.

And so we wandered on, beguiled by the stream, which kept on murmuring seductively of charms farther on.

We talked of the Angel-fish and their many attractions. Mr. Clemens told me of Margaret's last visit to Stormfield and of what good times they had had together. "She is a dear womanly child," said Mr. Clemens, "and we had one conversation together which convinced me more than ever of her sweet consideration for others. She was telling me how she intended to bring up her children, and what were her plans for their education. There were to be two, a boy and a girl. The girl was to be named after her mother. I asked her what the boy's name would be, and she replied, with a reproachful look in her brown eyes: 'Why, Mr. Clemens, I can't name him until I know what his father's name is.' Now, was n't that truly thoughtful?"

We finally had to leave the stream, for it was the lunch hour, so we made an abrupt turn and approached Stormfield by the oppo- 
site side from which we had left it. As we climbed the hill, Mr. Clemens paused a moment to say: "I never want to leave this place. It satisfies me perfectly." 



\section{Stormfield, Đappily Continued}




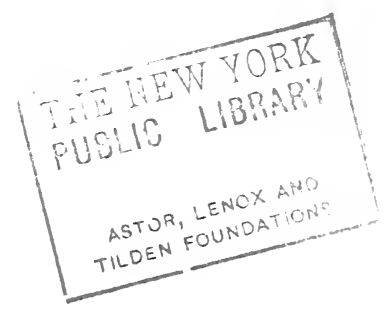




\section{CHAP'TER XII}

\section{STORMFIELD, HAPPILY CONTINUED}

$\Lambda \mathrm{T}$ luncheon Mr. Clemens spoke of his A lasting gratitude to Captain Stormfield. For it was to the success of his Heavenly Experiences that the building of the loggia was due. And that was the reason the peaceful house was thus christened.

Our meal was somewhat hurried by the announcement, made by the deeply-interested butler, that the people were beginning to come. We were to have that afternoon the first entertainment of a series for the benefit of the Library Fund of the village. Mr. Clemens had offered to tell stories, and the entrance fee was to be twenty-five cents.

Chairs had been hired from the local undertaker, and had been placed in close rows in the big living-room, in the loggia, and out in the hall. 
The first who arrived had walked five miles. More came. They came in buggies and in other handy vehicles. They entered the house solemnly and took their places silently, refusing to make themselves comfortable, and held on grimly to fur overcoats and fleecelined jackets. Soon the big living-room was filled to overflowing, and then Mr. Clemens stepped up to the improvised platform at one end of the long room and bade them welcome. As usual, he made a most picturesque appearance. On the wall behind him was a very large square, of carved, rich, old Italian oak, which filled the space between the two windows and formed an effective background for the white-haired, white-clad figure of the speaker.

Mr. Clemens told story after story in his happiest vein - how he became an agriculturist, how he was lost in the dead of night in the black vastness of a German banquetinghall. He was brilliant, wonderful. He seemed determined to bring a ripple into the faces of that silent audience. Once in a while stern features would relax for a moment, but the 


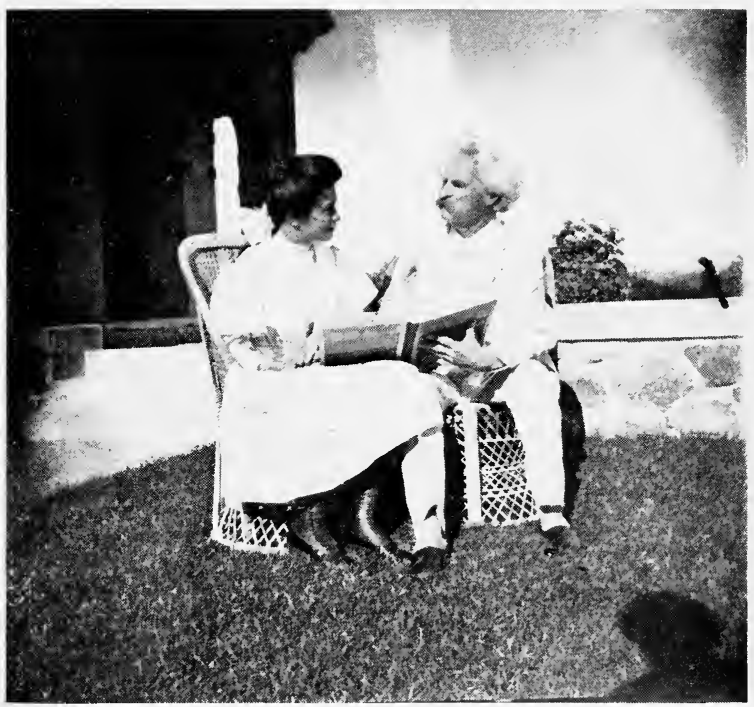

It was hard to tell which he loved best 


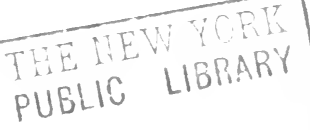

$$
\begin{aligned}
& \text { ASTUR, LENOX AND } \\
& \text { TILD: N FOUNDATIONS. }
\end{aligned}
$$


effort seemed to hurt, and the muscles would become fixed again.

In the back of the room there sat some of the younger generation, who suffered from occasional apoplectic outbursts. And yet we knew that everyone there was enjoying it deeply, hugely, only, as Mr. Clemens said afterwards, "they were n't used to laughing on the outside." And they were proud, too, proud almost to sinning, of their illustrious fellow-townsman, and they would have shouted with laughter, if they only could.

When Mr. Clemens had finished, after an entertainment of an hour and a half, there was no lack of applause. This they could give. The audience dispersed slowly, many of the number stopping to look, with openmouthed but inarticulate admiration, at the beauties and luxuries of this home, so different from theirs.

That evening Mr. Clemens rested himself by playing billiards. Before beginning, he showed me his collection of fish. Charmingly colored pictures of Angel-fish and other 
varieties were framed and hung low around the billiard-room. He told me that each real Angel-fish who came to visit him could choose one of those and call it her coat-of-arms.

There were other very remarkable sketches and caricatures hung on the walls, but Mr. Clemens seemed most interested in the piscatorial collection.

It was sometimes a wonderful and fearsome thing to watch Mr. Clemens play billiards. He loved the game, and he loved to win, but he occasionally made a very bad stroke, and then the varied, picturesque, and unorthodox vocabulary, acquired in his more youthful years, was the only thing that gave him comfort. Gently, slowly, with no profane inflexions of voice, but irresistibly as though they had the head-waters of the Mississippi for their source, came this stream of unholy adjectives and choice expletives. I don't mean to imply that he indulged himself thus before promiscuous audiences. It was only when some member of the inner circle of his friends was present that he showed him this mark of confidence, for he meant it in the 
nature of a compliment. His mind was as far from giving offence as the mind of a child, and we felt none. We only felt a kind of awe. At no other time did I ever hear Mr. Clemens use any word which could be called profanity. But if we would penetrate into the billiard-room and watch him play, we must accept certain inevitable privileges of royalty.

The next morning as I was going downstairs, Mr. Clemens called to me from his room, in a tone that made me hurry. He was standing by one of the many windows, and he said: "Come quickly and look at the deep blue haze on those barberry bushes! They have never looked quite like this before." Then he went on to say: "When they built this house they had the inspiration to put in these small panes. See how each one frames a wonderful picture, and I can have a different one every time I change my position. No man-made pictures shall ever hang on my walls so long as I have these."

And Mr. Clemens had no picture on his wall, except a portrait of his daughter Jean. 
That afternoon we took a long drive over the hills. Mr. Clemens kept no coachman and no carriage at that time, but when he wished a "rig" he sent word to the friendly farmer near by, who would soon appear with a surrey and a team of horses.

I remember that much of the talk that afternoon turned on the strange manifestations of genius and the tragic lives of many of those who were thus fatally endowed.

When evening came that day we asked Mr. Clemens to read Kipling to us again, and thus revive some of the memories of the Happy Island. And so we sat around the big blazing fire, and again the King's voice swept us out to visions of mighty action. More favorites were added. The Three Decker was read with unction, and The Long Trail was read twice over before the audience was satisfied. We wished that Mr. Rogers were there, and, happily, we did not feel the chill prophecy that some of us were never to see him again.

An hour before luncheon, on Sunday, we gathered together in the living-room. Someone proposed that Mr. Clemens read aloud to 
us from his book, What Is Man? Into this work Mr. Clemens had put some of his deepest convictions as to the meaning of life and the principles that guide the human soul. Whatever may be their philosophical value to others, he, at least, believed in them utterly, and when he read aloud to us the clear, trenchant dialogue, we, too, were convinced, for a time, of their truth. He grew so earnest that he would often repeat a phrase, twice, in a deep, solemn voice, and he so utterly forgot his pipe that it went out completely.

Our afternoon's peace was somewhat invaded by calls from the outside world and demands that Mr. Clemens should allow himself to be photographed. I often wondered how many thousand times the camera must have turned its eye upon him.

That last evening we played Hearts, for it still continued to be Mr. Clemens' favorite game. Again we missed Mr. Rogers sorely, and wished for his bantering. For no one else of us dared to chaff Mr. Clemens in quite the way that he had done. Besides, we knew that it would n't have been in the least humor- 
ous. We lengthened the hours as long as we could, for it was to be the last evening together, as the early morning train was to take me away.

Since we knew how averse Mr. Clemens was to saying good-by to anyone, we parted that evening with a simple good-night. I did not expect to see him again, but the next morning as I went down to my hurried breakfast I heard his voice calling me. I went to his room. He was lying in his big carved bed, propped up by pillows. On the little table beside him were crowded together pipes, cigars, matches, a bottle or two, and a number of books. He handed one of the books to me, and said, "You must have one of my souvenirs." It was a copy of Eve's Diary, with a kindly dedication in it on the fly-leaf. Then he said good-bye.

The November sunshine had gone. The chill of winter had come into the air, and as I drove over the hills to the station I felt that I was going away from something very wonderful and very precious. For the love and friendship of those who have their faces 
turned towards the sunset is sometimes as rare and sweet and unworldly as that of little children. Perhaps they both are nearer the infinite, and so can understand. 



\section{Letters}


<smiles>C=[AlH]</smiles> 


\section{CHAPTER XIII}

\section{LETTERS}

A FTER the happy visit at Stormfield we never saw Mr. Clemens again, but from time to time precious letters came from him, so characteristic that they vividly evoked his presence. He always wrote them in his own hand.

The first one preserved is one that he wrote in answer to an incident of which I had written him an account. I had been lecturing to a class of students on Victor Hugo, and I had dwelt upon the enthusiastic appreciation of Frenchmen for their great men of letters. I had added, as I remember, that we had not yet attained that advanced stage of civilization where we could make heroes of our literary men, and, warming up to my subject, I said that were I to ask the class sitting then before me who was the most beloved American writer, I much doubted if they 
could, spontaneously, name anyone. Seeing nods of dissent, I challenged them, and a dozen or more responded, "Mark Twain!" while the rest nodded approval.

His answer is as follows:

Stormfield, Reding, Connecticut, April 22/09.

Dear Betsy:

It is not conveyable in words. I mean my vanity - rotten joy in the dear and pleasant things you say of me, and in my enviable standing in your class, as revealed by the class's answer to your challenge. So I shall not try to do the conveying, but only say I am grateful - a truth which you would easily divine, even if I said nothing at all.

You must come here again - please don't forget it. We'll have another good time.

Affectionately,

S. L. Clemens.

In May he wrote in reference to Mr. Rogers's sudden death:

It is indeed, dear Betsy: a heavy stroke. It bruised many a heart: how many we shall never know, for his helpful kindnesses went far and wide and made no outward sign. Here we shall not look upon his like again; hereafter-

Affectionately,

$$
\text { S. L. C. }
$$




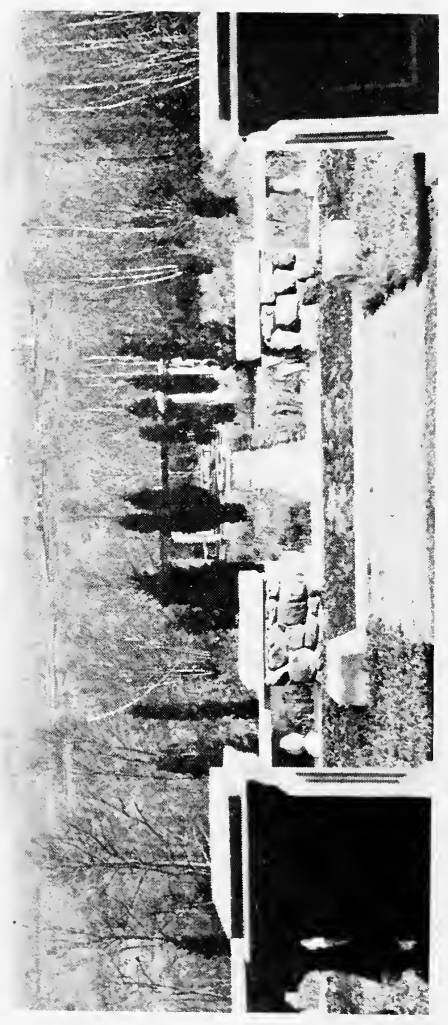

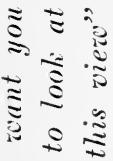

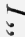



Another letter was concerning a paper which I had written about him, and which I did not wish to read in public without his sanction. He says :

I am leaving home for five days and the article will arrive here after I am gone, but I can tell you now that I'm not afraid to have you print anything you have written with me for subject - I don't need to see it first. I know all about it anyway, because Margaret's mother told me how charming it is. I saw her only a few days ago, when I went down to Irvington to see that dear little rascal play Puck in $A$ Midsummer Night's Dream. She did it well and I was proud of her. * * *

My present journey is to St. Timothy's School, where Francesca, another of my Fishes, will graduate next Thursday.

And thanks for the Kipling verses!

Affectionately,

S. L. C.

The envelope containing this letter had been broken, and across the end was written, "Broke it open myself. S. L. C."

There was a postscript added:

The mss. has arrived and I unseal my justfinished letter to say how grateful I am that you are able to say such beautiful things about me 
and to feel them. I thank you out of my heart.

I can suggest a correction or two, of no importance:

1. The Oxford degree is Litt.D.

2. My recollection is that the life of Henri IV was attempted 18 times - once for each year of his reign - a pretty striking coincidence, you see!

The next letter is without date. After speaking of some other matters, he says:

To change the subject: will you come? And bring or send Mr. S-? For you and he are of the sort that can entertain themselves and be entertained by the household, counting me out mainly. I can't ask any other kind, for I went to Baltimore early in June, and the fatigue and the raw weather brought a return of what happened in August last. So I can stand but little fatigue and am not down stairs much. I was warned to stop smoking, which I did, for two or three days, but it was too lonesome, and I have resumed - in a modified way - 4 smokes a day instead of 40 . This will have a good effect. On the bank balance.

I have delayed scandalously in the matter of returning the MSS., but I will have it mailed today or tomorrow sure.

Affectionately, 
I almost hesitate to quote from his next letter, and yet what he says is so characteristic of one side of him, the opposite of the gentle self-control and sweetness which he was so beautifully capable of exercising, that it seems only fair to give at least an extract.

There - I have enjoyed treating the subject with a pen, for I am full of malice, saturated with malignity. I feel nearer to the Lord than I ever was before. I feel as $\mathrm{He}$ feels of a Saturday night when the weekly report is in and $\mathrm{He}$ has had a satisfactory clean-up of the human race.

I can't walk, I can't drive, I'm not downstairs much and I don't see company; but I drink barrels of water to keep the pain quiet; I read, and read, and read, and smoke, and smoke, and smoke all the time (as formerly), and it's a contented and comfortable life.

I had sent him a copy of Thompson's beautiful appreciation of Shelley, to which he replied:

Stormfield, Sept. 22/09.

Dear Betsy:

It is a lovely little book, and as rich in sumptuous imagery as is Shelley himself. The reading so moved and charmed me that I read 
some Shelley under the inspiration of it. Thank you ever so much for sending it.

But the Angel-fishes are not "company." They are part of the family. They come, and dear me, how welcome they are!

That little rascal [Margaret] will come, I think, when she gets located at Greenwich near-by - where her next school is. . . .

We had a grand time here yesterday. Concert in aid of the little library.

\section{Team.}

Gabrilowitsch, pianist.

David Bispham, vocalist.

Clara Clemens, ditto.

Mark Twain, Introducer of Team.

Detachments, and squads, and groups, and singles came from everywhere - Danbury, New Haven, Norwalk, Redding, Redding Ridge, Ridgefield, and even from New York; some in 60 motor cars, some in buggies and carriages, and a swarm of farmer-young-folk on foot from miles around: 525 altogether.

If we had n't stopped the sale of tickets a day and a half before the performance we should have been swamped. We jammed 160 into the library (not quite all had seats); we filled the loggia, the dining-room, the hall, clear into the billiard-room, the stairs, and the brick-paved square outside the dining-room door.

The artists were received with a great welcome, and it woke them up, and I tell you they 
performed to the Queen's taste! The program was an hour and threc-quarters long, and the encores added a half hour to it. The enthusiasm of the house was hair-lifting. They all stayed an hour after the close, to shake hands and congratulate.

We had no dollar seats except in the library, but we accumulated $\$ 372$ for the Building Fund. We had a tea at half past six for a dozenthe Hawthornes, Jeanette Gilder and her niece, ctc.: and after 8 o'clock dinner we had a private concert and a ball in the bare-stripped library until 10: nobody present but the team, and Mr. and Mrs. Paine, and Jean and her dog. And me. Bispham did Danny Deever and the Erlkönig in his majestic great organ tones and artillery, and Gabrilowitsch played the accompaniments as they were never played before, I do suppose.

It having been decided that smoking was in no way responsible for my malady, I'm smoking as much as ever now.

Affectionately,

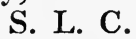

A later letter tells of the wedding of his daughter Clara, in most happy vein. He was perfectly satisfied. He adds, towards the last:

Jean abides with me, and runs a farm and keeps my accounts. . . . No, I have n't any 7-page letters from Margaret-no letters at 
all, in fact. She and her mother were to visit me last week. My Bermuda Angel-fish has been here. She has grown considerably, but is as sweet and innocent and unspoiled as ever she was.

I sent you Booth Tarkington's little Xmas book the other day. I hate Xmas stories, but this one is bright and felicitous, and has n't any religion in it, and I like it.

I've written a Xmas thing myself, for the Bazaar, but if it has any religion in it I did n't notice it.

I had spoken in one of my letters about Anatole France's book, l'Ile des Pingouins, and had ordered a copy to be sent to him. In reply this letter came:

Dear Betsy:

Stormfield, Nov. 13/09.

No, I have n't read it, but you make me want to read it - hungry to read it, in fact. I am all ready for it. Meantime I've been writing "Letters from the Earth," and if you will come here and see us, I'll read passages to you. This book will never be published. Paine likes it, but then, Paine is going to be damned anyhow.

The autumn splendors passed you by? What a pity. I wish you had been here. It was beyond words! It was heaven and hell and sunset and rainbows and the aurora, all fused into one divine harmony, and you could n't look 
at it and keep the tears back. All the hosannahing and strong gorgeousnesses have gone back to heaven and hell and the pole now, but no matter: if you could look out at my bedroom window at this moment, you would choke up; and when you got your voice you would say this is not real, this is a dream. Such a singing together, and such a whispering together, and such a snuggling together of cosy soft colors, and such kissing and caressing, and such pretty blushing when the sun breaks out and catches those dainty weeds at it-you remember that weed-garden of mine? - and then - then the far hills sleeping in a dim blue trance-oh, hearing about it is nothing, you should be here to see it.

Good! I wish $I$ could go on the platform and read. And I could, if it could be kept out of the papers. There's a charity-school of 400 young girls in Boston that I would give my ears to talk to if I had some more; but - oh, well, I can't go, and so it's no use to grieve about it.

This morning Jean went to town; also Paine; also the butler; also Katy; also the laundress. The cook and the maid, and the boy, and the roustabout and Jean's coachman, are left-just enough to make it lonesome, because they are around yet never visible. However, the Harpers are sending Leigh up to play billiards; therefore, I shall survive.

Affectionately,

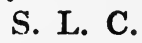


Soon after the date of this letter, Mr. Clemens went to Bermuda to make a short stay. A card came from him, postmarked December 17th, and bearing the following:

Merry Christmas and affectionate greeting to Betsy. Maude has been close-clipped and looks elegant - even spiritual.

\section{S. L. C.}

His visit to Bermuda was brief, and he came back to Stormfield to spend the holidays with his daughter Jean. Then came the sad tragedy which robbed him of this daughter, and he was left alone, for his daughter Mrs. Gabrilowitsch had gone to live in Europe. On New Year's day he wrote:

I can't write, for I am ill with a cold - the first one $I$ have had in two years. The pain in my breast has come back - so I am leaving for Bermuda next Wednesday, for an indefinite stay.

I enclose a sheet which I wrote to Clara to comfort her. I shall stay with the A-s, if they've got room for me.

Always affectionately,

S. L. C. 


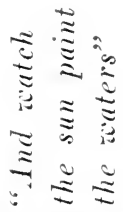

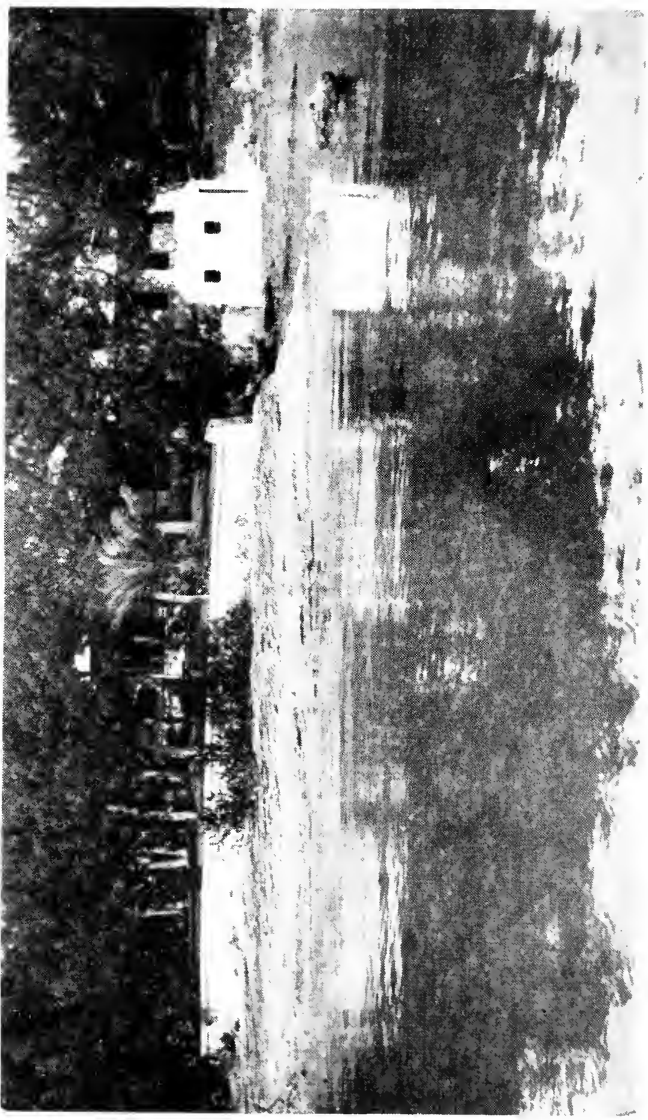




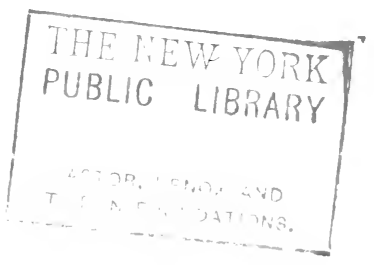


The enclosed sheet to which he refers is touchingly sweet. There are two sentences which I may perhaps quote. In speaking of Jean's death he says: "I am so glad she is out of it and safe-safe!"

And, further on: "I am not melancholy; I shall never be melancholy again, I think."

$\mathrm{He}$ is again in Bermuda, and, seemingly, much better. He writes:

\section{Bermuda, Jan. 26/10.}

Dear Betsy:

No, revelation - of a valuable sort-does not come through sorrow when one is old. I am happy - few are so happy - but I get none of this happiness from knowing more of the unknowable than I knew before. Jan. $29-$ noon. I intended to be lazy and dictate the rest of this, but my little secretary (Helen, Angelfish) has escaped, and gone bicycling with a schoolmate. I am guest in her parents' house indefinitely. I never feel a desire to visit Stormfield. . . . I have Claude, best of butlers, valets and everything else, with me. He lives at the Hamilton House, but is in close touch with me by telephone and bicycle. . . . Helen has been gone an hour and a half, and will have to be severely scolded. Did you ever try to scold an angel-fish? I think a person 
could learn to do it. But he would have to have considerable practice.

Good-bye. Affectionately,

$$
\text { S. L. C. }
$$

There was added, in a childish hand, the following apology :

Mr. Clemens wants me to say I am sorry. So I say I am sorry.

Helen S.-A-, Secy.

The last letter bears date of March 12th.

Dear Betsy:

If I were to start over again I would be a Reformer. I certainly would. There would be an increasing interest in it that would pay handsomely for all the hostilities I should raise.

I wish you had given me the name of your pretty and sweet friend who sailed for Bermuda the other day. I would have hunted her up. You know that, well enough. Maybe she looked for us in the donkey-cart - but I have n't been in it. Helen requires swifter transportation than that.

You ought to be here now! The weather is divine; and you know what it is to drive along the North Shore in such weather and watch the sun paint the waters. We had that happiness today. The joy of it never stales. . . . 
There are no newspapers, no telegrams, no mobiles, no trolleys, no trains, no tramps, no railways, no theatres, no noise, no lectures, no riots, no murders, no fires, no burglaries, no politics, no offenses of any kind, no follies but church, and I don't go there. I think I could live here always and be contented.

You go to heaven if you want to-I'd druther stay here.

As ever affectionately,

S. L. C.

P. S. I have been reading Chapter XIII of "A Yankee in King Arthur's Court." Bless you. I find it good.

Six weeks later, his friend and official biographer, Albert Bigelow Paine, wrote me: "Yes, he is resting. If you had seen his calm face as I saw it for the last time on Sunday, you would know how peacefully."

And so the King left us. But the Happy Island, where we learned to know him and love him, will always be for us enchanted ground, and his throne is secure in the kingdom of our hearts. 





W.

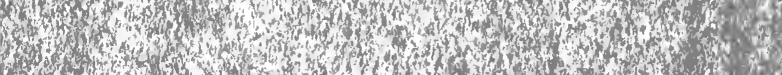

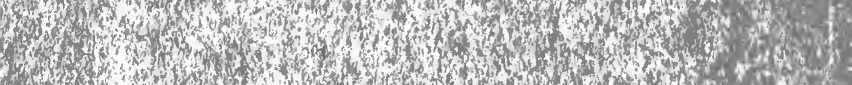

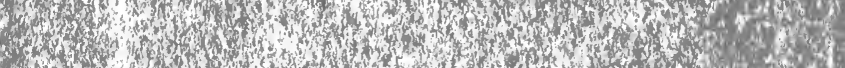

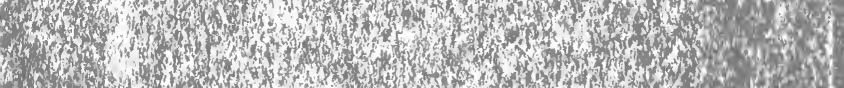
6.

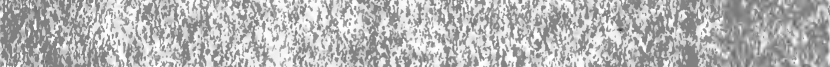

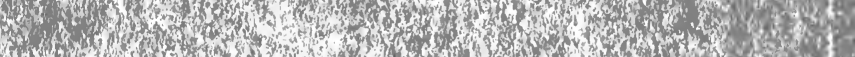

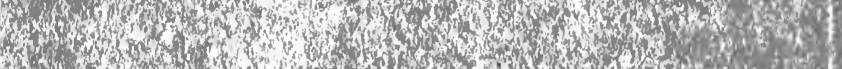
Wom

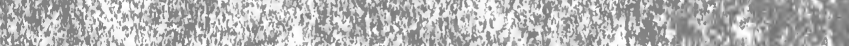
1.

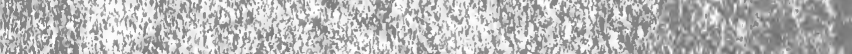

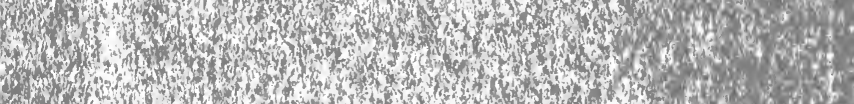

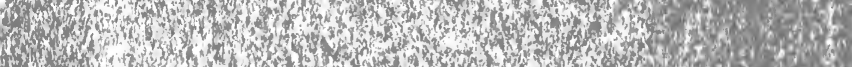

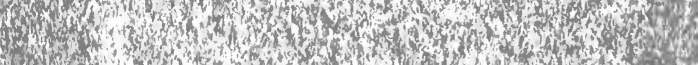
9 10.

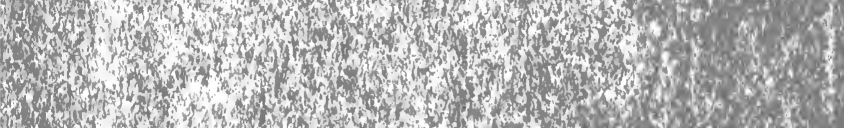

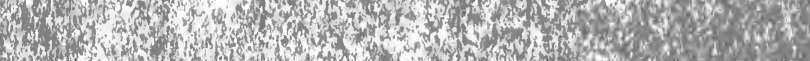

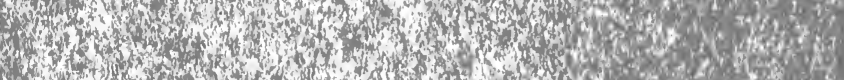

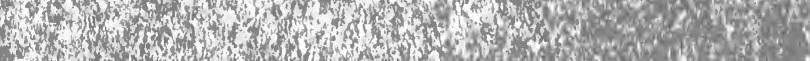



